Florida International University FIU Digital Commons

\title{
The Ashram of Swami Jyotirmayananda: Examining Authority, Transmission and Identity within the Guru and Disciple Relationship
}

Priyanka Ramlakhan

priyaram32@yahoo.com

DOI: $10.25148 /$ etd.FI14040882

Follow this and additional works at: https:// digitalcommons.fiu.edu/etd

Part of the American Popular Culture Commons, New Religious Movements Commons, Race, Ethnicity and Post-Colonial Studies Commons, and the Social and Behavioral Sciences Commons

\section{Recommended Citation}

Ramlakhan, Priyanka, "The Ashram of Swami Jyotirmayananda: Examining Authority, Transmission and Identity within the Guru and Disciple Relationship" (2014). FIU Electronic Theses and Dissertations. 1202.

https://digitalcommons.fiu.edu/etd/1202 


\title{
FLORIDA INTERNATIONAL UNIVERSITY
}

Miami, Florida

\section{THE ASHRAM OF SWAMI JYOTIRMAYANANDA: EXAMINING AUTHORITY, TRANSMISSION AND IDENTITY WITHIN THE GURU AND DISCIPLE RELATIONSHIP}

\author{
A thesis submitted in partial fulfillment of \\ the requirements for the degree of \\ MASTER OF ARTS \\ in \\ RELIGIOUS STUDIES \\ by \\ Priyanka Ramlakhan
}


To: Dean Kenneth G. Furton

College of Arts and Sciences

This thesis, written by Priyanka Ramlakhan, and entitled The Ashram of Swami Jyotirmayananda: Examining Authority, Transmission and Identity within the Guru and Disciple Relationship, having been approved in respect to style and intellectual content, is referred to you for judgment.

We have read this thesis and recommend that it be approved.

Steven Heine

Albert Wuaku

Nathan Katz, Major Professor

Date of Defense: March 20, 2014

The thesis of Priyanka Ramlakhan is approved.

Dean Kenneth G. Furton

College of Arts and Sciences

Dean Lakshmi N. Reddi

University Graduate School

Florida International University, 2014 


\section{DEDICATION}

sri gurave namah

I dedicate this thesis to the primordial guru. 


\section{ACKNOWLEDGMENTS}

There are several individuals I would like to thank whose guidance and support led to the completion of this study. First and foremost, I thank my revered guru, Swami Jyotirmayananda for a lifetime of inspiration and for granting me the privilege of conducting a research study at the Yoga Research Foundation. I would like to thank my committee chair, Dr. Nathan Katz for his encouragement and counsel from the commencement of my graduate studies; your teachings will remain with me for the rest of my career. I thank my committee members Dr. Albert Wuaku for sharing his expertise in fieldwork and Dr. Steven Heine for his invaluable insights. I would also like to make special mention of my graduate program director, Dr. Oren Stier for his support throughout my graduate career. To my cohort, you inspire me and each of you have left a tremendous impact on my life. Katharine Pals and Alexander Fernandez, thank you for the many enriching conversations during our research process.

This research study would also not have been possible without the participation of the disciples of Swami Jyotirmayananda. I extend my gratitude to Swamini Divyananda, Swamini Sharadananda, Archana, Sri Hari, Vasudeva, Prana, Padma Devi, Maheswari, Sri Arjuna, Ambika, Ramesh, Sankara, Radha, Mukunda, and Bhavani for graciously narrating your spiritual journeys and allowing me to share them on the pages of this thesis. To all the disciples at the Yoga Research Foundation, who were informally part of this study, I thank you.

Finally, I would like to thank my mother Amala and my father in heaven, Ramroop for always encouraging me to pursue my dreams no matter how strange or far they took me from home. 


\section{ABSTRACT OF THE THESIS \\ THE ASHRAM OF SWAMI JYOTIRMAYANANDA: EXAMINING AUTHORITY, TRANSMISSION AND IDENTITY WITHIN THE GURU AND DISCIPLE RELATIONSHIP \\ by}

Priyanka Ramlakhan

Florida International University, 2014

Miami, Florida

Professor Nathan Katz, Major Professor

The wave of gurus in America brought with them cultural transformations particularly in how they interpret Hinduism, how their teachings have adapted in engaging a Western audience, and the sustainability of their religious communities, thus changing the landscape of contemporary Hindu spirituality. The traditional model of the guru and disciple relationship according to Yoga and Vedanta is undergoing a transformation allowing for greater autonomy of the disciple to make decisions in how they appropriate the authority of the guru. This thesis examines the guru and disciple relationship within the institutional organization of the Yoga Research Foundation, founded by the contemporary guru, Swami Jyotirmayananda. Research of Jyotirmayananda's unique following of Western disciples illuminates the nature of his authority through the establishment of his order and methods by which disciples navigate identity formation and experience religious transmission. 


\section{TABLE OF CONTENTS}

CHAPTER

PAGE

PREFACE

1

CHAPTER 1 INTRODUCTION ...................................................................... 4

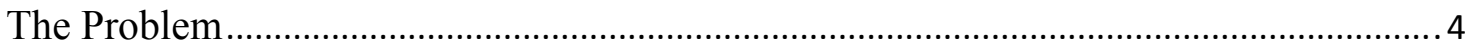

Methodology \& Theoretical Framework ……................................................................... 4

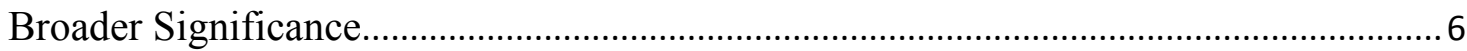

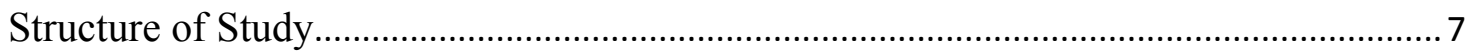

The American Guru and Disciple Relationship ......................................................... 8

CHAPTER 2 LITERATURE REVIEW …....................................................... 9

Hinduism - An Understanding through Tradition and Modernity ................................. 9

Hindu Schools of Thought Relevant to Study .............................................................. 13

Neo-Vedanta Movements and the Transitioning Role of the Guru..................................17

Hinduism and Guru Movements in the West ................................................................... 20

CHAPTER 3 RESEARCH DESIGN AND METHODOLOGY ................................... 25

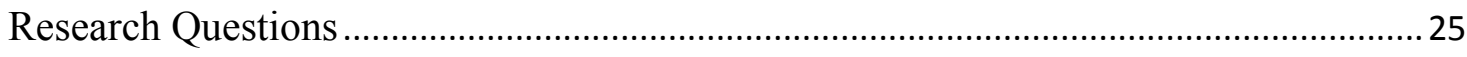



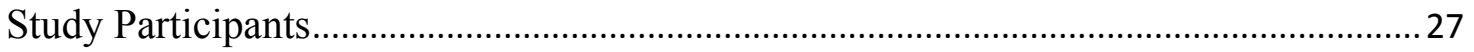

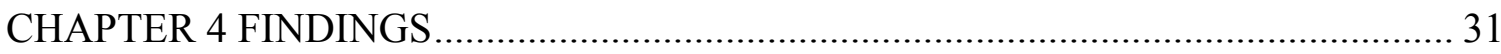

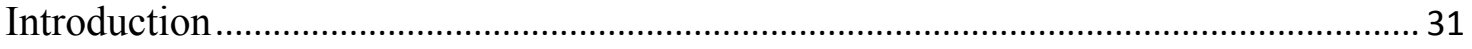

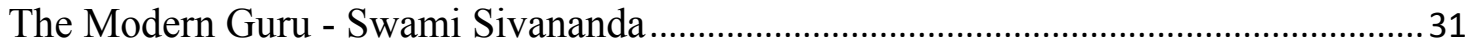

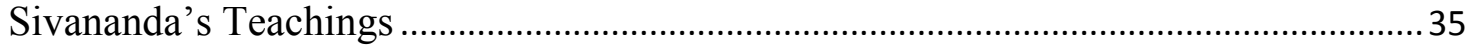

Sivananda's Analysis of the Guru and Disciple Relationship.........................................36

Swami Jyotirmayananda's Account of Swami Sivananda.................................................. 39

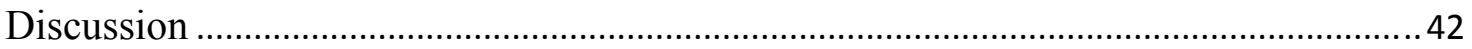

Swami Jyotirmayananda - His Life and Teachings......................................................... 43

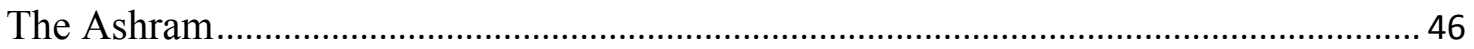




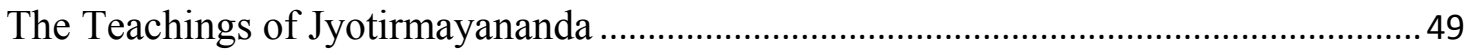

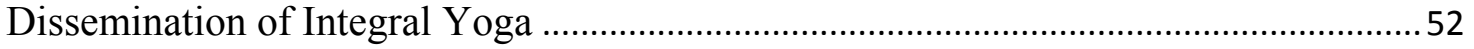

Swami Jyotirmayananda's Analysis of the Guru and Disciple Relationship ..................55

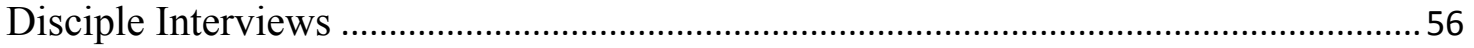

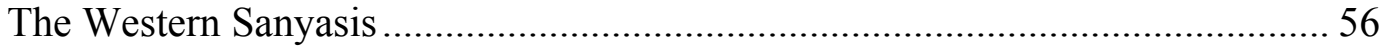

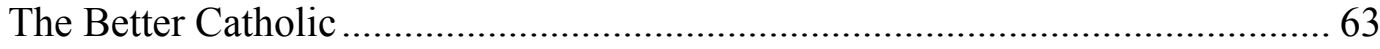

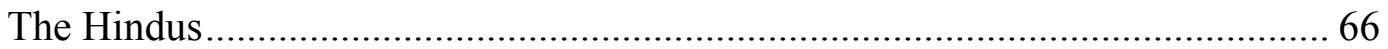

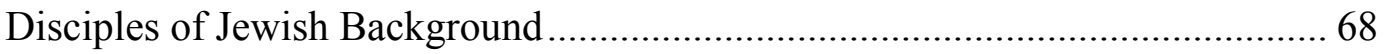

The Spiritual but not Religious, and Mostly a Vedantist.................................... 70

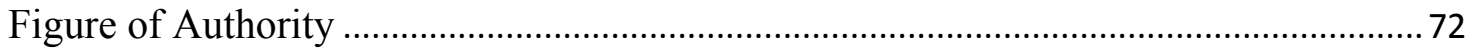

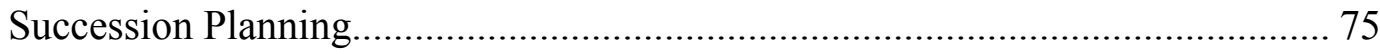

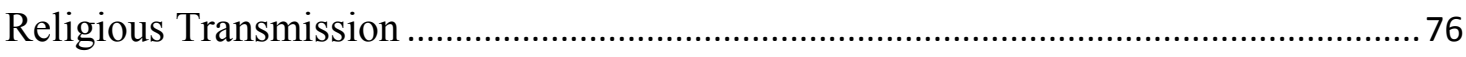

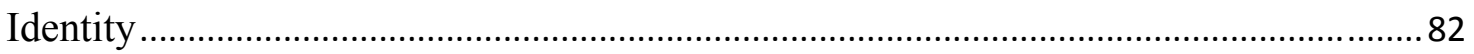

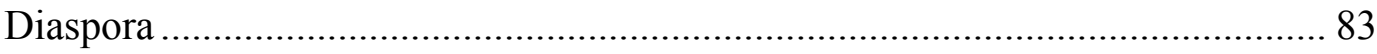

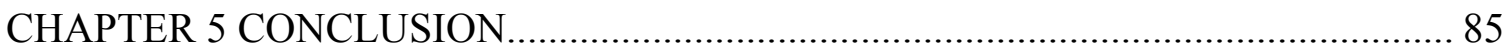

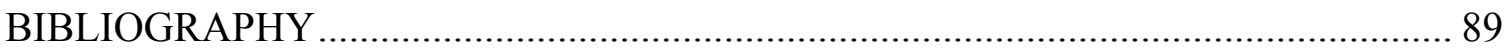




\section{PREFACE}

In this section I address my personal and academic interests influencing this study as my personal history is deeply connected to this ethnography.

The study was inspired by my quest of understanding my identity as a disciple of a guru and the nature of religious transmission and devotion I had experienced for the greater part of my life. Being in the presence of what most would refer to as "realized" and "enlightened" masters, I understood the guru to be a teacher possessing great capabilities, some even supernatural and the likened them to a God-like status. Later in life, a more rational understanding that gurus were also individuals and perhaps my attraction to them was predicated upon being raised in a Hindu household dominated by prayer, study of scripture and guru worship.

My highly religious upbringing and deep interest in Hindu philosophy inspired my engaging in traditional studies in the Sandeepany Sadhanalaya ashram founded by Swami Chinmayananda in Mumbai, India and then at the Yoga Research Foundation, founded by Swami Jyotirmayananda in Miami, Florida. I have had a lifetime affiliation with each organization; however the contemporary guru Swami Jyotirmayananda held a particularly influential role in my life as he is my guru.

At the age of five I was first introduced to Swami Jyotirmayananda, and in 1995 at the age of ten, I was conferred initiation. I mention this initiation ceremony as it was at this moment I experienced a resounding intuitive knowing that Swamiji was my guru.

In November of 2009, I joined the Yoga Research Foundation full time to pursue studies under the tutelage of Swami Jyotirmayananda. I lived in Jyotirmayananda's 
ashram as part of a work-study scholarship for two years, after which I moved nearby maintaining regular involvement in ashram affairs. During this work-study program I engaged in the study of Hindu scriptures and Sanskrit, hatha yoga, transcription of Jyotirmayananda's lectures, editing of YRF publications, assisting with preparation of the monthly magazine as well as ashram chores like cleaning, kitchen duties, and preparing initiation ceremonies. Part of my study program further included conducting devotional offerings in the form of song and discourse upon the Bhagavad Gita.

During these years I came to understand the guru and his close group of disciples on a personal level. It wasn't until one day I found myself sitting in the lecture hall of Swami Jyotirmayananda's ashram in Miami and observing that on any given day I was one of two or three Indian Hindus present. As the remainder of the congregation was of mixed race and religious affiliations, I became highly interested in the nature of the Western individual's experience of the guru and questioned both their interest and allegiance to a guru of a different religio-cultural background. Belonging to the IndoCaribbean diaspora myself, Vedanta and Yoga offered teachings of an identity that was greater than a remembered homeland, and I became curious if other dispersed populations shared a similar experience. Furthermore, I was eager to understand the subtleties of how spiritual knowledge was transferred through a mystical channel from the guru to the disciple and its correlation to the perception of identity.

Though unaware of how this research would be facilitated and without clarity of its direction, I found my answer during my first Religious Studies graduate course, Religions of India, taught by Dr. Nathan Katz at Florida International University. Dr. 
Katz' graduate seminar was dedicated to gurus of modernity, and it was here this study began formation.

My study was made possible by participant-observation access within the Yoga Research Foundation. Insider-status afforded me immense tools in illuminating the cultural portrait of Jyotirmayananda's ashram (Ellis 8). The research contained in this thesis has deeply impacted my understanding of the guru and disciple relationship on both an academic and personal level. 


\section{CHAPTER 1 INTRODUCTION}

\section{The Problem}

The research contained in the current thesis is offered as a contribution to the literature on gurus and the ever transforming guru and disciple relationship. Specifically it is a report of how one particular guru, Swami Jyotirmayananda through his organization, the Yoga Research Foundation in Miami, Florida participated in the rethinking of this classical relationship contributing to the changing landscape of Hinduism spirituality in the United States. My study has given attention to the issues that arise out of the reciprocal relationship of the guru and disciple such as authority, religious transmission and identity. Scholars interested in guru studies have addressed such issues, however in the current study much disparate scholarship will be engaged to illuminate new hypotheses as I incorporate their findings and views. The research opens the door to questions of how transference of religious and spiritual knowledge occurs from one individual to another? Do ethnic diversity, language barriers, geographic region or variant world views stand as an obstacle in transmission and discipleship? As we live in a world where mainstream gurus have asserted their presence and have become a structurally sound member of society, this ethnography sheds light upon a guru who has toiled in relative obscurity from his contemporaries and illuminate his unique following of American disciples.

\section{Methodology \& Theoretical Framework}

Frameworking the research from an autoethnographic perspective, my study engages personal experience and interacts these with key informants through participant- 
observation (Ellis 47). The examinations of social and individual human behaviors including the affective processes of the individual were conducted through semistructured and open-ended interviews eliciting narrative responses. Narratives became the source of method and the phenomenon as I gathered oral histories and stories from the guru and his disciples (Creswell 54). Interviewing fifteen disciples with varying tenure as initiates I began my analysis by extracting keywords, emerging themes and character typologies from interview transcriptions. I present five specific case studies that are representative of my findings. Qualitative data gathered through books, journals, newspaper articles, and audio and video archives at the Yoga Research Foundation comprise the remainder of research not obtained through direct interviews of Swami Jyotirmayananda and his disciples. The methodology used herein affords a comprehensive dialogue as to the guru's authority and facilitation of disciple's perception of religious transmission and identity formation. Epistemologies engaged in the research involve the understanding of how race creates itself as a social and religious construct and why its vital understanding dismantles the enculturalated nature of Jyotirmayananda's ashram.

Engaging with the theoretical and analytical framework that inform my research, I draw upon Turner's theory of liminality that interprets the breaking-down and re-making of the individual, or the "in-between" stages, in translating how disciples position their identity before, during and after 1) initiations 2) religious transmission and 3) religious/spiritual phenomena. Turner, drawing upon Van Gennep's three-tiered structure of ritual passage (Gennep 21) will help identify the disciple's liminal status during the religious transmission process, which is otherwise structurally invisible 
(Andrews 23). Engaging the theory of liminality further explains how a disciple appropriates authority onto the guru throughout their change process, the nature of affective process and the individual quest for freedom and identity. Weberian concepts examine the dialogic relationship between the guru and disciple and interpret to what extent the rational, traditional and charismatic grounds of authority are represented through Jyotirmayananda's leadership.

\section{Broader Significance}

I aim to provide contemporary research in the transitioning nature of the guru and disciple relationship within the Yoga Research Foundation of Miami, Florida led by the Indian guru, Swami Jyotirmayananda. The nexus within Miami presents a unique following of American disciples whose study illuminates broader implications of how Eastern models can exist in Western culture. In addition, the study reveals how the institutional structure of the YRF has undergone a rethinking of how Americans understand Vedantic "Hinduism" and marked changes in religiosity of Western disciples who adopt a distinct religio-spiritual identity. Examination of religious transmission answers the questions of continuity and succession planning both within this order and with relation to its parent lineage in Rishikesh, India. Through this approach, conclusions can be drawn as to how the Sivananda lineage continues to influence the trajectory of Hindu spirituality. The present study makes further contributions through describing methods by which Jyotirmayananda constructed a new model of how ashram life can work in the United States, as I contend with existing definitions of discipleship. In sum, my research adds to existing literature and explores how Hindu thought continues to 
penetrate the West and its development of new pedagogical styles in catering to a Western audience.

\section{Structure of Study}

Chapter one provides an introduction, the theoretical framework, methodology and epistemologies engaged in this study. Chapter 2 establishes the origins of the guru in Vedic narratives and the major stands of Hindu thought. As the ideology and practice of guruship has reconstructed itself overtime, classical, medieval, modern and contemporary understandings of the guru shall be illuminated. I further identify the findings of landmark studies conducted on guru and disciple relationships. Chapter three will display the Sivananda ashram through the lens of scholarship, literature recounting primary sources and interviews with Swami Jyotirmayananda, a foremost disciple of Sivananda. A brief life sketch of Jyotirmayananda, the establishment of his ashram and tenure as both a disciple and guru will be explained in chapter four. Next, I present the findings of my ethnography specific to the guru and disciple model, transmission of knowledge and authority of the guru as informed by Swami Jyotirmayananda's disciples. I conclude this research in chapter five where I analyze the findings of this ethnography and identity how it sits with modern scholarship and finally establish a firm understanding of how the transplantation of the guru and disciple relationship has transformed within the Yoga Research Foundation of Swami Jyotirmayananda. 


\section{The American Guru and Disciple Relationship}

The guru and disciple (shishya) relationship is integral to the Hindu tradition and provides an important thread by which religious transmission can occur (McMullen 9). For many Americans, the understanding of the guru as a teacher imbued with religious authority is familiar as they become part of a centuries-old tradition by identifying themselves as disciples (Forsthoefel and Humes 3). With the interaction of Hinduism in the United States, the traditional model of the guru and disciple relationship is undergoing a transformation allowing for greater autonomy of the disciple to make decisions in how they appropriate the authority of the guru and assimilate Vedantic teachings within their lifestyle.

The wave of Hindu gurus in America brought with them "cultural transformations" particularly in how they interpret Hinduism, how their teachings have adapted in engaging a Western audience, and the sustainability of their religious communities, thus changing the landscape of the guru and disciple relationship (4). The transplantation of this classical relationship and its permutations within its host culture can be observed through the organization of the contemporary guru, Swami Jyotirmayananda. The research of his following of American disciples serves to examine the nature of his authority through the establishment of his order and methods by which disciples navigate identity formation and experience religious transmission. 


\section{CHAPTER 2 LITERATURE REVIEW}

\section{Hinduism - An Understanding through Tradition and Modernity}

'Hinduism' is a term given for a "diverse and complex religious tradition” (Jacobs 1).

Originally the term 'Hindu' is a Persian word that geographically located people who lived near the Indus river and is derived from the Sanksrit word sindhu. By the end of the eighteenth century, "Hindu' was used by the British to denote people who lived in Hindustan within northwest, India (Flood 6). In the 1830s, '-ism' was included to differentiate the "culture and religion" of upper-caste Brahmans to other religions, while later it became accepted to include the many traditions of South Asia. However, Hinduism and her multiple strands have gone beyond these borders and taken on a new identity and new followers with its transplantation into western countries. Contemporary Hinduism is further defined by modern gurus who have reimagined the tradition bereft of the word 'Hindu.' Sanatana dharma or eternal religion is the preferred terminology of Hindu practitioners who seek to depart from Oriental influence and re-establish Vedic heritage.

Understanding the true import of what it means to be a Hindu might be a futile attempt as much scholarship contends there can be "no such thing," regardless my study requires a preliminary study of its complex history (5). A vast range of traditions and ideologies are suggested by the single term 'Hindu,' however most traditions regard the revelatory literature of the Vedas as a central part of their discourse, whereas others attach great importance to ritual-yielded salvation and theistic approaches (6), nevertheless this still does not begin to define it. Flood remarks that it becomes further 
confused as the struggle for defining Hinduism lies in individual interpretation in "what we mean by religion (8)." Durkheim, in The Elementary Forms of the Religious Life, defines religion "as unified set of beliefs and practices relative to sacred things" and becomes the most appropriate descriptor in advancing this study (Durkheim 62).

Six schools of thought comprise Hindu philosophy. The term 'philosophy' has posed a problem for many scholars, however for the purpose of further defining 'Hinduism' its use will be adopted (King 24). King has elucidated the Hindu philosophical perspectives in the form of groupings:

"Nyaya-the school of logic

Vaisesika - the school of atomism

Samkya - the school of dualistic discrimination

Yoga - the school of classical yoga

Mimamsa - the school of Vedic exegesis

Vedanta - the school based upon the Vedas (i.e., the Upanishads).

...The schools are usually grouped into couples (as above) according to their perceived affinities. Thus, Nyaya and Vaisesika represent the 'empirio-logical' strand of Hindu culture, Samkhya and Yoga share an interest in attaining liberation (moksa) through isolation of pure consciousness from matter, while Mimamsa and Vedanta exemplify an approach grounded in the exegesis of the sacred Vedas" (45-6).

The practices of Hinduism can be loosely understood as containing one or more of the following elements with one strand being more pronounced: "meritorious action (karma), transcendent insight (jnana), or loving devotion (bhakti)." Each of these strands exist in the six schools of Indian thought and include any number of the following: 1) sacrifices to local deities 2) Vedic sacrifices to gods 3) journeys to pilgrimage centers 4) bathing in ceremonial or sacred water 5) worship (puja) of a divine image 6) devotional singing of god's name 7) disciplinary ascetic practices and 8) meditative techniques 
including breathing and posture. Each strand as well as their respective practices is designed to lead to the practitioner to the attainment of liberation (moksha) (Brady 1011). Prakash describes the evolution of Hindu life as "based on an organic conception of nature. According to it nature is so organically constituted that all its acts emerge from the convergence of the functions of its whole system and effect in turn, the working of its whole process," comparing its tradition to process of a sprouting seed that turns into a tree (Prakash 495).

Within Hinduism, the function of the guru is of utmost importance as both gurus and guru-founded organizations have been instrumental in "constructing, interpreting and transmitting religious means and values to their followers in the Indian subcontinent and beyond" for centuries (Warrier 169).

The Sanskrit word guru has no one single meaning, being derived in many ways and according to different traditions: 1) gur - 'to raise, to lift up, to hurt, to kill, to make effort, to eat, to go.' 2) $g r$ - 'to sing, to swallow.' Tantrik literature defines guru through the blending of its Sankrit roots, ' $g u$ - darkness,' and ' $r u$ - what restrains it.' ' $G u$ ' also relates to 'truth of the self' or that which is guhya, meaning secret. In another definition, 'gu' is the giver of fulfillment, ' $r$ ' the destroyer of sin, and ' $u$ ' is Vishnu. One might find a contradiction in these derivations; however the guru becomes the 'giver of fulfillment' revealing the 'secret' of the 'truth of the self' by 'restraining/killing/swallowing, etc.' 'darkness' (McMullen 9). Peter Brent defines the guru through five key functions:

The function of the Master, the guru is complex and perhaps essential. He is, first the focus of the disciple's attention and emotion...Second, the guru, a human being demonstrably similar to the disciple, sets the experience within a human scale...Third, it is clear that the guru can help the disciple directly, either by explaining difficulties, helping to solve 
problems...even by violence. Fourth, he is the example, the proof that the way leads somewhere...And possibly, fifth, he may be a source of developed mental power which, transferred to the disciple can transform the latter's inner life" (Brent 339).

Within the Advaita non-dualistic school of thought the guru is essential to the "realization of the Absolute (Brahman) (Dhavamony 91). The student of the guru is known as the shisya and only when the guru and shisya live under the same roof through the gurukula system can knowledge be transferred. The guru and shisya bond is highly personal as traditionally the shisya looks towards the guru as not only a source of knowledge but a source of all relationships. Many paths of knowledge are described in the Upanishads but brahmavidya (knowledge of Brahman) is a specific knowledge that may only be transferred through a teacher-disciple medium (Cenkner 15). The student aspires to be like the guru in every way and the guru reciprocates through instilling within the student the experience that led to their own self-realization (16). A teacher within the text of Taittariya Upanishad instructs his student, "Speak the truth. Practice righteousness. Make no mistake about study. Having offered the desirable wealth to the teacher, do not cut off the line of progeny. Do not be careless about learning and teaching." In this way, the lineage between the spiritual preceptor and disciple remain intact and allow for the succession and continuity of teachings (19).

\section{Establishment \& Continuity of a Lineage}

Gurus are understood as the core support of Hindu traditions as they meditate the entire process of religious continuity as they engage in debating other guru's interpretations as well as contending through their own (Warrier 169). "Hindu monastic 
orders are organized around the concept of a teaching tradition (sampradaya) related to a famous teacher who first enunciated the philosophical religious system of the order (Miller 4)." Spiritual lineages (guruparampara) of specific teaching traditions traces back to Sankara. Gurus who become recognized as famous generally mark the beginning of a new sampradaya (Baird 87). Miller has attributed the structural casing of sampradayas as similar to a pattern of ever growing circles of which the guru is the center. The innermost circle consists of the guru's closest disciples and may include ashram lay disciples. Another group of lay disciples are those who live outside of the ashram but frequent it and provide its financial support. The establishments of lay sister organizations often fall in the hands of this type of laity. The locus of the circle is always the guru who is described as an invisible pull that continuously attracts disciples towards the center. When the guru dies, there exists a void unless a charismatic leader rises to "pull his fellow disciples back to the center" and provides continuity of the sampradaya (Baird 88).

\section{Hindu Schools of Thought Relevant to Study}

The primary focus of this study relates to the Yoga and Advaita Vedanta teaching lineages, therefore I present a basic understanding of each school of thought as they later serve to define the teachings of Swami Jyotirmayananda and his organization, the Yoga Research Foundation.

Yoga

The Yoga school was primarily established through Patanjali's first century of the Common Era work on the Yoga Sutras. The darshana echoes similar concepts regarding 'nature' and its way of being found as in its sister tradition, Sankya (Larson 487). Both 
the definitions of yoga in its living tradition and its original text differ. The word yoga is derived from its Sanskrit root yuj, Larson discusses:

Panini notes two roots yuj in his Dhätupätha, the first in IV.68 as yuj samädhau (root yuj in regard to concentration) and the second in VII.7 as yujir yoge (root yuj in regard to yoking or harnessing or uniting). Vacaspatimis'ra points out that both he and Vyasa understand the word yoga in the former sense and not the latter sense in Patañjali's Yogasütra. In other words, in Patañjala Yoga yoga does not mean 'union'; it means, rather, samädhi (Larson 490).

The Yoga Sutras consist of a string of aphorisms (sutras) that systematize its doctrine and practice. The tradition of Patanjali was later extended by commentaries and independent works from Vyasa, Vachaspati Mishra, and Viijnanabhikshu among others (Vareene 1812). Hatha Yoga which consists of postures and breath techniques, though different, may also have been derived from Patanjali’s Yoga system (Larson 493).

The objective of Yoga is concerned with the attainment of liberation of the soul and draws heavily upon the Sankya model. However, though Sankya is an atheistic tradition, Yoga accepts the concept of a God termed as ishwara and is "a special kind of self (purusha) that has not been entangled by matter (prakriti)." The theistic tradition of Yoga is developed in the sixteenth century by Vijnanabhikshu and initiates the coalescing of Sankya Yoga and Vedanta as "he attempts to reconcile the pluralism and atheism of Sankya with the monism of some forms of Vedanta" (Flood 235).

\section{Vedanta}

Flood posits Vedanta is the most influential body of theology within India. It is unclear by scholars whether its eight century founder, Sankara belonged to the Saiva or Vaishnava traditions. Contemporary scholarship further posits Vedanta is an expression 
of the earlier Mimamsa school (Flood 238). Vedanta traditions include "Advaita ('NonDualist') Vedanta, Vasishtadvaita ('Qualified Non-Dualist') Vedanta and Dvaita ('Dualist') Vedanta" (239).

The premise of Vedanta is predicated upon Sankara's question of, "Who am I?" as he develops upon Upanishadic ideology that forms the last portion of the Vedas. (Dhiman 17). The objective of Vedanta is to understand the nature of the atman, the Self and one's identity through the process of Self-knowledge or atma vidya. Self knowledge is crucial to Indian philosophy as it postulates that an individual must first know who they are before they can relate to the world around them (17). Advaita is the most popular tradition of Vedanta and establishes that the Self and Brahman are identical, there only lies a veil of maya (illusion) separating them.

The Self exists in three states of waking, dream and deep sleep, and to understand the Self, one must derive information from each of these states. Throughout these states, the Self remains changeless and of the nature of satchitananda-existence, knowledge and bliss. The experiencer of these states is the jiva, the individual embodied soul. What obscures the vision of knowing the Self is the non-self, this is ignorance and the root cause of ignorance is lack of knowledge. Ignorance is termed as avidya and knowledge as vidya. The student of Vedanta seeking knowledge of the Self must first be equipped with the qualifications of 1) discrimination (viveka) — distinguishing the real from the unreal, 2) dispassion or renunciation (vairagya), 3) six virtues (shatsampatti)self-control and 4) aspiration for liberation (mumukshutvam). Ideally the student approaches a spiritual preceptor or guru after they have gained these four qualifications (18). The method of Vedanta is partially one of "discriminative negation" as it 
understands that properties of the unreal are superimposed onto the real through ignorance, this is explained by the classic metaphor of the rope-snake. One is able to peel away the layers of the not-self with the understanding of the five sheaths characterized as the food, vital air, mind, intellect and bliss sheaths (21). The body, mind, intellect and senses also all fall within the realm of the sheaths whereas the Self does not. The purpose of teaching the 'sheaths' is to instill the idea of continuous negation through neti-neti, meaning "not this, not this." Moreover, even though the linguistic protocol is to not associate "I" with the body, mind and intellect, the "I" is implied. This "I" is representative of the Self that gives sentiency to the "instruments" of the body, mind and intellect. Vedanta philosophy as expounded by Sankara, establishes that there is a difference between the "seer," or the subject and the "seen," or the object. The subject is of the nature of pure consciousness and is all-knowing. When an object is seen, it is because it is conditioned through maya and is like seeing a rope but believing it to be a snake. Furthermore when an object is able to be cognized, or as Vedanta would say, contained within a thought-wave, then it cannot be the Self as the Self cannot be understood through cognition (Sivananda 1973, 23).

Overall, there is a constant push and pull effect that occurs between the understanding the unity of Brahman and the multiplicity of Maya. However, upon understanding the illusion of maya as a potency of Brahman and its quality of being real nor unreal, the inquirer gains knowledge bringing about the destruction of ignorance (Oldmeadow 6). In sum, "It is Sankara's purpose to awaken us from this dream, to awaken the true Self and to Reality through Right Knowledge" (Oldmeadow 23). Within India and the West, Advaita Vedanta is most popularized though having a complicated 
history of philosophical debates concerning its metaphysics (Flood 249). Within global Hinduism, Advaita Vedanta was transformed into a new expression by politicians and gurus during the nineteenth-century Hindu Renaissance, also known as a period marked by Neo-Vedanta (Flood 265,269).

\section{Neo-Vedanta Movements and the Transitioning Role of the Guru}

In modern times, the function of the guru evolved based upon the needs of society, specifically the factors of modernity and response to colonial rule (Warrier 169). Thus the guru departed from traditional paradigms of classical teachings and became advocates for Indian nationalism and social relief, blending each. Neo-Vedanta, also referred to as neo-Hinduism and neo-Advaita became one of the dominating forces for organizing Indian ideology for the purpose of uniting Hindus in struggling for freedom from British rule and has had profound effect upon the "modern notions of the 'spiritual' or 'mystical' nature of the Hindu religion. Swami Vivekananda was a major contributor to the neo-Vedanta movement in India and abroad (King 135). However Vivekananda was not the sole contributor to the efforts of neo-Vedanta, others like the former prime minister Sarvepalli Radhakrishnan and Orientalists deeply influenced this movement and further redefined the motive of neo-Vedanta holding Advaita ideology at its core (King 135). Overall, neo-Vedanta is something of reconciliation for minds of Indian Hindus in regaining their once lost intellectual standard derived from Vedic lore. With this also took place the "vedanticization" of other systems of Hindu thought particularly through Radhakrishnan's popular work, The Hindu View of Life: "The Vedanta is not a religion, but religion itself in its most universal and deepest significance. Thus the different sects 
of Hinduism are reconciled by a common standard and are sometimes regarded as the distorted expressions of the one true canon" (135).

Modern reformer Rammohan Roy (1772-1833) the founder of the Brahmo Samaj, is regarded as "the Father and Patriarch of Modern India" and contributed greatly to religious and social facets of nineteenth century Hindu community (Hatcher 52). His movement marks the first of neo-Vedanta (Farquar 22). Rammohan envisioned an interpretation of monotheistic Hinduism and emphasis on the learning of English especially through the translation of Upanishads into English (Hatcher 57). Possibly drawing from mutazilite theology or Enlightenment logics he preached a "simple code of religion and morality" that could be derived from all religions (58). Hatcher explains that the appearance of Rammohan marks a "recognizable break" in "the logic of the tradition/modernity dichotomy" and its intellectual movement (54), however Chatterjee contends that such categories cannot be precisely be marked in the "general theory of change in society" (55).

The role of the guru became decentralized during the rise of the Swami Dayananda and the Arya Samaj movement. His belief was that all truth lay in the Vedas and de-emphasis on "idolatry, polytheism, Puranas, priestly privilege, popular rituals and deities," believing only Vedic Hinduism revealed the truth (Baird 27). In preaching his own version of Hinduism, Dayananda traveled outside of India establishing Arya branches (29). In 1880, while the Arya Samaj was growing in numbers another movement within India that would become world-wide planted roots in the form of an illiterate guru, Ramakrishna. Ramakrishna's teachings were one of tolerance in that the 
stress of conversion or complete rejection of religious faith was unimportant in conveying his "oneness of truth" (59).

The foremost disciple of Ramakrishna, Swami Vivekananda spread the teachings of his guru through the monastic order of the Ramakrishna Math. "This movement has been credited with championing the cultural revival or renaissance of modern India, defending the total religious heritage of the Hindu tradition when others were in retreat and purifying Hindu monasticism so that its members have become exemplars of Indian spirituality (55).” Ramakrishna mission was constructed upon the principles of monotheism, monastic life, universality_preaching message of sanatana dharma, tolerance, non-sectarianism, liberal, humanitarian, progressive and scientific (56-7). Vivekananda was the first Swami of India to bring the knowledge of yoga and Vedanta to the west. He lectured and wrote pamphlets in English on the Yoga disciplines of gyana, bhakti, karma, and raja. The development of English literature on Hindu concepts for American and European audiences became a major contributor to the transnational movement of yoga and Vedanta. (Strauss 217).

The Divine Life Society is recognized as another major movement in NeoHinduism. Swami Sivananda having been inspired by Vivekananda emulated organizational aspects of the Ramakrishna Mission including how knowledge was disseminated. This is especially observed in the way monastic order has been emphasized through sanyas initiation and the medium of English language used for impacting a greater population.

Overall, throughout history religious elements of Hinduism have transformed and owe its adaptations to contact with Islam in the medieval period and influence of 
Christianity in the modern period. Carman discusses that "such influences are most likely to occur in one of two situations: either contact of the greatest point of similarity....or the borrowing from one's opponents in the process of defending oneself intellectually from "outside" influences (Brady 12)." Modern transmission of Indian tradition changed through the dissemination of knowledge through printed literature, a technique adopted from Christian missionaries (13).

With Indian traditions finding new means of transmission within India, it becomes interesting to understand how this transmission occurred from India to North America and the position of Indian immigrants and American Hindu converts practicing Hinduism in the United States.

\section{Hinduism and Guru Movements in the West}

The first engagement of Hinduism studies in the West began in the seventeenth century when European explorers came in contact with Indian languages which subsequently initiated the translations of Sanskrit sacred texts. One of the earliest known English translations of the Bhagavad Gita is authored by Charles Wilkins in 1785 (Sastri 1). Friedrich Rosen was the first investigator of Vedic literature in 1838 and his students including the most notable, Eugene Burnouf (1801-1852), Rudolph Roth (1821-1895) and Friedrich Max-Muller (1823-1900) continues his work. The publication of the History of Indian Literature by Albrecht Weber (1825-1901) was one of the early and most influential works of Indology (Sastri 3). Early essays of Ralph Waldo Emerson (1803-1882) impactful upon American culture made mention of Vedic literature, the Laws of Manu, the Visnu Sarma, whereas later in his career "the Hindu connection is 
more explicitly drawn (632), with the Visnu Purana and the Bhagavad Gita becoming major works of focus for his writing (637).

...in all nations there are minds which incline to dwell in the conception of the fundamental unity...this tendency finds its highest expression in the religious writings of the East, and chiefly in the Indian scriptures, in the Vedas, the Bhagavat Geeta, and the Vishnu Purana. Those writings contain little else than this idea, and they rise to pure and sublime strains in celebrating it (Emerson 95).

Later the writings of Emerson were heavily influenced by the early period of European Sanskrit scholarship particularly by William Jones (1746-1794), Henry Thomas Colebrooke (1765-1837), Friedrich Schlegel (1772-1829), and Eugene Burnouf (18011852) (Goodman 626). Thoreau among others, inspired by Emerson and Orientalism became part of the Transcendental movement, a contemporary to the Theosophical society in the United States, beginning in 1874 that sought to resurrect occult ideology and Eastern philosophy (Gomes vii-1). Influential figures of the Theosophical society included Madame Blavatsky (1831-1891), Henry Steel Olcott (1832-1907) and Annie Besant (1847-1933). Later figures like Mahatma Gandhi (1869-1948), became critical to the modern development of Hindu thought and social reform (Brown 26; Jackson 165, 168).

Therefore prior to arrival of Swami Vivekananda, quite possibly the first Indian guru on American soil, Western civilization had already begun its preoccupation with Hinduism. As the presence of religiously diverse traditions led by gurus increased, many became full-fledged organizations, developing their own specific disciplines and ritualistic observances. One such trend theorized by Lola Williamson is the HIMMs'Hindu inspired meditation movements' that began their transplantation during the turn of 
the nineteenth to the twentieth century. This strengthened by the great influx of Indian gurus during the 1960s further highlighted the presence of Hindu thought within the US as both teachings and discipleship gained immense popularity. With regards to the HIMM, though meditation did not exclusively belong to Hinduism, its adoption into mainstream culture as well as its sister components like karma theory, Yoga and the study of Hindu texts became popularized through Indian gurus, who very often did not acknowledge that they themselves were Hindu though basing their teaching upon Hindu doctrines and rituals (Williamson 4).

The three major groups of the HIMM were founded by the gurus Parmahansa Yogananda, Maharishi Mahesh Yogi and Swami Muktananda. Parmahansa Yogananda arrived in the US in 1920 and organized the Self Realization Fellowship (SRF) in 1935, a body of teachings that collectively centered on a system of meditative disciplines called Kriya Yoga (6). The continuation of the Spiritual Regeneration Movement established in India in 1958 and founded by Maharishi Mahesh Yogi, became the Transcendental Deep Meditation (TM) movement in the US in 1961 and further founded another organization, Students International Meditation Society. The third major meditation group founded by Swami Muktananda's specialized meditation system was 'Siddha Yoga,' and officially established the Siddha Yoga Dham Associates (SYDA) in 1975.

Bhakti movements also made their presence during the mid-twenty first century, the most prominent being the International Society for Krishna Consciousness (ISKCON), or Hare Krishnas headed by the guru Srila Prabhupada. The Vaishnava society was essential in the forming a new strand of 'American Hinduism,' that propagated traditional Indian societal practices including the dressing styles, diet and 
arranged marriages. Coupled with these traditional adoptions, was the engagement of a devotional approach of worship to a personal God.

Vedanta movements were prevalent and included the organizations of the Ramakrishna Mission, founded by Swami Vivekananda, the Vedanta Society, the teachings of Sri Chinmoy and Swami Sacchidananda (Goldberg 187). Each of these organizations produced massive writings greatly adding to the presence of Vedanta literature in America.

Tantra, a path that "attempts to integrate opposites," regards the divine feminine or the Devi as the highest manifestation of God and is characterized by ritual. Rajneesh also known as Osho and Adi Da are two gurus who propagated and popularized Tantrik worship. The notable presence of disciples of other Indian gurus belonging to different lineages who taught a different facet of Hinduism but not physically present in the United States were Sri Aurobindo, Anandamayi Ma and Sathya Sai Baba, Ramana Maharshi and Swami Sivananda. Traveling gurus like Sri Sri Ravi Sankar, Krishnamurthy, Sant Keshavadas, and Hari Das Baba further added to the presence of Indian gurus in the twentieth century (193). With the immensity of Indian gurus there naturally arose western disciples like Papaji, Gangaji and Sri Daya Mata, who themselves became gurus and either established or continued their guru's teaching organization (Williamson 6-8).

Consequently, the neo-Vedantic understanding of 'Hinduism' and the 'guru' has evolved throughout history as invasions of the medieval period and reformers of the nineteenth century have reimagined its tradition (Jacob 129). Furthermore, the globalization of Hinduism was largely influenced by guru-led movements and the propagation of their mission through their disciples (Flood 265). As the both the 
visibility and influence of Indian gurus and their disciples saturated Western culture, naturally scholars began to research their movements. Surveying relevant literature on the guru and disciple relationship, inter-related themes emerge such as the nature of the classical relationship itself and its individual and social constructs, the ontology of identity construction based upon Hindu tradition and the transnational movement of Yoga and Vedanta and possibly simultaneously the revitalization of Hinduism. 


\section{CHAPTER 3 RESEARCH DESIGN AND METHODOLOGY}

The purpose of chapter 3 is to present the methodology used to answer the questions of my study. Chapter 2 introduced the Hindu schools of thought and terms specific to the study and presented the landscape of the transplantation of major strands of Hinduism in the United States revealing a gap as to the circumstance of present day guru-led organizations. My study was conducted to gather data on the guru and disciple relationship within the Yoga and Vedanta lineage of Swami Jyotirmayananda and determine how Western disciples of this Indian guru assimilate his teachings through the experience of religious transmission.

\section{Research Questions}

1. What are the teachings and pedagogy of Jyotirmayananda and how is it similar/dissimilar from that of his guru Sivananda with regards to guru and discipleship and to what extent has Jyotirmayananda's teachings transformed so as to appeal to an American audience?

2. What is the basis of the guru's authority according to his disciples?

3. What are the observed and investigated methods of religious transmission and what variables (including individuals) must be present for transmission to occur and how do disciples posit their identity?

As several themes dominate the scope of the guru and disciple relationship, here I clarify the research questions so as to narrow its focus. Research question 1 interacts a historical snapshot of the ashram of Swami Sivananda, his general teachings and those specific to guru and discipleship and a firsthand account of his disciple, Jyotirmayananda 
who further illustrating is ideals on guruship. Answers to research question 1 become the basis upon which I am able to compare the organizations of Sivananda and Jyotirmayananda and derive explanations as to how the lineage itself has undergone changes. The second research question engages the discussion of how disciples understand the authority of the guru and what factors contribute to their extended discipleship. The third research question deals specifically with methods of religious transmission of knowledge between the guru and disciple, and how researched methods facilitate its transference. This question engages the use of ritual, initiation as well as direct and indirect teachings from the guru. Transformation of religious identity and placement within the lineage reveal how Western disciples navigate identity formation and the adoption of a new set of religious practices and beliefs as well as their terminology used to describe its phenomenon. The research design and data collection methods will be explained in the remainder of this chapter.

\section{Research Design}

Conceptualizing the research process guided by the initial research questions I draw upon qualitative methodology. The methodology is most appropriate as I reveal "how a cultural group works to explore the beliefs, language, behaviors, and issues such as power, resistance and dominance" (Creswell 70). Being an initiated disciple of Swami Jyotirmayananda of eighteen years led me to consider combining elements of autoethnography along with ethnographic accounts of study participants. I employ the strategy of participant observation as I am associated with an established role within this scene (Atkinson 248). As the religious organization behaves as a separate group within 
society, observation is critical in determining is culture and nuances. My status as an insider facilitated the process in determining gatekeepers and key informants and seeking permissions for the current research study. My emic perspective within this organization and history with disciples aided in securing study participants and fostering a level of trust during interviews, becoming the basis upon selecting subjects of this culture-sharing group.

Throughout the data collection process I was increasingly aware of the anthropological undercurrents such as judgments, observations and perceptions that may be biased due to my status as an insider of this group. During interviews, I also became keenly aware that semi-structured sessions afforded the greatest opportunity to yield narrative responses unaffected by the structure in which I asked the question, allowing disciple responses to flow in an unadulterated manner.

\section{Study Participants}

The guru, Swami Jyotirmayananda and fifteen of his disciples were selected for participation in the present research study. Fifteen participants consisted of adult men and women of various ages, world views, education and each of varying degrees of tenure as a disciple of Swami Jyotirmayananda. Subjects were informed of the nature of this research study through the IRB authorized informational letter and signed the IRB consent form. Subjects were selected according to their identification as a disciple and willingness to participate. None of these subjects are of Asian descent and all are US born Americans or have spent more than $75 \%$ percent of their life in the United States. 
These subjects were also not raised with a traditional Hindu upbringing and fully adopted aspects of Hindu lifestyle and practice in their adult age. Some of these participants had prior exposure to Hindu, Buddhist and Zen philosophies and have had an existing guru prior to their discipleship of Swami Jyotirmayananda. Subjects were self-initiated into the path of spiritual quest for the varied reasons of general seeking, revelation of life's purpose, resolution to depression and tragic life events and to escape from the rigidity and inclusiveness of existing religiosity. Furthermore, subjects consisted of insiderdisciples, outsider disciples and those initiated into the monastic tradition of sanyasa (renunciation). To most adequately answer my research questions, two full-time resident disciples, as well as two disciples on the executive leadership board, initiated sanyasis and lay disciples of varying household status were interviewed. To my surprise, most subjects expressed great enthusiasm to be part of this study and all were interested in its final outcome.

\section{$\underline{\text { Interview Questions }}$}

Questions specific to the guru:

1. Why did you decide to become a teacher of Vedanta?

2. Do you recognize yourself as a guru?

3. How do you place yourself within the guru lineage (parampara)?

4. What does it mean to be a guru?

5. What does it mean to be a disciple?

6. Describe Sivananda's teaching style.

7. Describe the initiation process.

8. How is knowledge transferred from the guru to the disciple?

9. What is the future of this organization?

Questions specific to disciples:

1. What is your name (both legal and initiated)?

2. What year were you born?

3. What is your religion? 
4. Are you a disciple of Swami Jyotirmayananda?

5. Is Swami Jyotirmayananda your guru? Why?

6. What makes him a guru?

7. Why did you first begin attending the Yoga Research Foundation?

8. Explain your involvement and practices related to the Hindu tradition.

9. Explain the religious organizations or communities in which you attend.

10. Explain what led to your religious/spiritual involvement and the nature of the religious practices you observe.

11. Explain your opinions on the guru-disciple relationship, authority, initiation and transference of knowledge.

The sources of data for the current study are comprised primarily from subject interviews through secondary sources. Interviews were semi-structured according to the major aforementioned subject areas. Subjects often felt comfortable deviating from the core questions expanding the interview with information they felt relevant, often describing highly personal life experiences. Within these instances, being a disciple turned researcher became useful as I had an existing rapport with participants. Interviews were conducted on a one-to-one basis on the ashram premises in either the satsang hall or in its workshop and lasted between thirty minutes to two hours. Participants were informed of the nature of the research project and informed of its recording. Narratives of seven disciples will be presented and analyzed within the five categories of 1) the initiated sanyasis 2) Catholic/Christian disciples 3) Jewish disciples 4) the Hindus and 5) the spiritual but not religious disciples. Each of the case studies I present illuminates distinct components within the guru and disciple relationship and are categorized according to groups that have the most similar typologies.

Within each category I coded narrative responses according to observably repeated themes. Each of the fourteen interviews were transcribed in its entirety and coded thereafter. In the support of my arguments, along with interview findings, I will also 
include excerpts from published disciple appreciations that appear each year in the institution's monthly magazine.

Additional sources of data include audio and video archives from lectures group gatherings (satsangas), monthly magazines, published books, unpublished manuscripts gained from archival research and permission from the institution's editor. Having been a resident of the ashram for two years and worked on publications with the guru and the editor afforded the present study knowledge of resources in gathering informative data and gaining permissions from administration. Regularly attending ashram events and volunteering services in administration enhanced my ability to efficiently navigate the inner workings of the culture-sharing group including symbology, terminology and etiquettes. This became influential in interweaving observation, archival research, primary accounts as it interacted with the researcher's experience. Informal conversations during this time also informed my research explaining the general function of the ashram, perceptions towards fellow disciples and the guru and general attitudes. Overall, though adhering to the structure of my initial research questions, emerging themes within the data collected directed the study.

As the methodology has been explained I present the subsequent chapters detail my researched findings and comparisons and conclusions. Chapter three will begin with historicizing the lineage itself through its founder monk, Swami Sivananda and the establishment of his organization, the Divine Life Society. Thereafter I present background information of his disciple Swami Jyotirmayananda and my fieldwork. 


\section{CHAPTER 4 FINDINGS}

\section{Introduction}

In this chapter I first begin by exploring the life, organization and teaching philosophy of Sivananda through primary and secondary sources. I specifically elaborate on the platform of the teachings of Vedanta philosophy and Sivananda's teachings that inform the guru and disciple relationship and include the ethnographic account of Jyotirmayanda. Thereafter, a life-sketch of Jyotirmayananda along with a discussion of his religious institution and teachings is explained. Thorough descriptions of the nature of the ashram community including the day-to-day practices are elucidated to give the reader a complete portrait of this community. I further analyze the pedagogy of Jyotirmayananda to demonstrate to what extent religious syncretism occurs and its influence in drawing Western discipleship. The ethnographic accounts from disciples comprise the next part of this chapter. I present their cases according to groupings of disciples that exhibited the most similarities in their interview responses. Finally, engaging data gathered from the sources previously described I analyze it through the lens of my theoretical framework. I now begin the discussion by examining the modern guru Swami Sivananda, the founder of the lineage being studied.

\section{The Modern Guru - Swami Sivananda}

The forming a new religious movement emerges from social conditions and need of the society, and often requires a leader of great charisma to organize that movement (Gyan 102). Swami Sivananda in many ways followed the style of Vivekananda in his approach to revitalizing Hinduism through the mass dissemination of knowledge in Hindu thought 
and practices. The Divine Life Society, also known by name 'Sivananda Ashram', was founded by Sivananda in 1936. Sivananda however was not always a religious teacher. Prior to his immense period of asceticism and sanyas initiation he was known as Kuppuswami and worked as a physician in Malaysia.

There exists a limited amount of literature on the early life of Sivananda despite Sivananda writing an autobiography. The handwritten pages of the self-published autobiography identify the details of his spirituality and illuminate his philosophy on life rather than a historicizing of his life. Miller discusses that Sivananda found it insignificant to write about his own life as it was not "directly beneficial for the spiritual progress of the reader" (Baird 89). There are but a handful of works that reveal the intimate details of the life this monk; the scholarship of Gyan, Strauss and Miller and two separate biographies written by disciples, Venkatesananda and Ananthanaryana (Gyan 1980, Strauss 2002, Miller 2009, Venkatesananda 2006, Ananthanaryana 1964). It is from these sources I derive the historical data on life of Sivananda.

\section{Life-sketch}

Swami Sivananda was born as Kuppuswami Iyer in 1887 to a Brahmin family in Tamil Nadu. During his adult years he earned a Western style medical education and upon completion he gained employment at a pharmacy. It was during this time that he began his soon to be prolific career by conceptualizing and authoring "The Ambrosia," a medical magazine. Accepting a job offer in Malaysia, Kuppuswami traveled abroad and continued to practice medicine in Malaysia for 10 years (Strauss 222). Beginning to become dissatisfied with worldly living, Kuppuswami regularly sought the company of holy men and immersed himself in the deep study of Hindu spirituality. During an 
occasion at the hospital he treated a sanyasi (monk) who later gifted him a text entitled Jiva-Brahma Aikya Vedanta Rahasyam by Cuddapah Sacchidananda Swami. The treatise on Vedanta gave Kuppuswami the urge to devote his life to sadhana (spiritual discipline) (Ananthanarayan 21). Through the course of gaining counsel from several religious teachers in Malaysia and practicing various disciplines of yoga, Kuppuswami returned to India, Rishikesh specifically; at the foothills of the Himalayan mountains to pursue a life of renunciation.

In Rishikesh, at the Kailash ashram, Kuppuswami became an ordained sanyasi and was renamed Swami Sivananda Saraswati. In 1936, he founded the Divine Life Society and began a dynamic movement of dissemination of literature on Vedanta and Yoga philosophies in the English language. From the inception of his organization, he quickly understood the need for technology and organized a printing press for the purpose of mass-distribution (Strauss 223). Swami Sivananda through his extensive publications wrote about his own life and experiences as well as commentaries in classical Vedanta and bhakti texts. From the prolific pen of Sivananda, 340 books and pamphlets in English were published from 1929 to 1963 . The notable 816 page translation and commentary on the Bhagavad Gita established him as a Vedantic scholar of the Advaita system identifying him as part of the sampradaya or teaching tradition of acharyas like Sankara (788-820) and Ramanuja (ca. 1500) (Baird 99). On July 14, 1963, on the banks of the Ganga river, Swami Sivananda Saraswati attained mahasamadhi, the term given for the death of a sanyasi. Mahasamadhi Sthana is the memorial that has been built for the burial of Sivananda. 
As mentioned previously, a sampradaya is the Sanskrit term given for a teaching tradition. Teaching traditions within Hinduism stem from specific lineages according to one of the six schools of thought propagated, and these lineages originate from an acharya or great teacher. Other such acharyas from the time of the Upanishads are Sankara, Ramanuja, Nimbarka and Vallabha. The Sivananda spiritual lineage or guruparampara belongs to the Advaita-Vedanta sampradaya of Sankara. Confirmation of his lineage can also be gleaned from his teachings focusing on the prasthanatrayi, the classical texts of Vedanta and their reference to Sankara's bhashya (commentary).

Miller describes the phenomenon of the Hindu concept of lineage in a succinct manner:

If we were to look closer at the structural elements of a sampradaya, we would discern a pattern of ever and ever larger circles moving outward from the center, much as heat waves emanate from a blazing fire. Yet at the same time the "pull" or movement is toward the center. The guru is at the center of the sampradaya and those nearest to him are his closest disciples, most often ascetics who have taken initiation into sannyasa of brahmacharya. Equally close are lay disciples who live at the monastery and share in its life...Just as fire will die out if not rekindled, so also a monastic movement will die with the death of the guru unless a charismatic disciple is able to pull his fellow disciples back to the center (Baird 87-88).

Though the Sivananda lineage belongs to the teaching tradition of Sankara, scholars understand Sivananda to be a guru that sprang up as he did not live the traditional life of discipleship. He never lived with a guru and primarily practiced his spiritual austerity in solitary places. Despite this, he is mentioned of having a diksha or an initiation guru of Swami Visvananda who conferred sanyas upon him (DLS 15). Sivananda writes in his autobiography on the experience of sansyas initiation:

In search of a guru, I reached Rishikesh and prayed to the Lord for his Grace. There are many egoistic students who say: "I need no guru, God is my guru." They change their own robes and live independently...The 
glory and the liberty of a Sanyasi can hardly be imagined by the timid and the weak. From the sacred hands of Paramahamsa Vishwananda Saraswati, I received holy initiation on the banks of the Ganges on 1st June, 1924. The religious rite of Viragja Homas was done for me by my Acharya guru, Sri Swami Vishnudevanandaji Maharaj at Kailas Ashram (Sivananda, 1980, 24).

\section{Sivananda's Teachings}

Vedanta as it is understood today has transformed through history, commentators, and religious interaction with India's many conquerors. Yoga was also developed as a separate tradition but often merged with Vedanta teachings as is clearly observed within the Sivananda lineage. Religious syncretism between Vedantic, Yogic, and Christian thought is widely present and was likely a response to the teaching of exclusivity of the Christian missionaries of that time (Wessinger 173). Sivananda greatly emphasized equality between individuals and the varying religious traditions pervasive in India during his time.

Quoting the Upanishads, Sivananda says in his autobiography, "All this is verily the Atman, The One, blissful Self in-dwells in all beings." He propagated the "oneness of humanity" was in great need and the message of living a divine life was to recognize the divine presence in each individual and offer love, compassion and service to them. Sivanananda was a believer in religion and extolled that all religions of the world declare the same divine message. "Know well that the heart of the Vedas, the heart of the Bible, the holy Koran, the sacred gathas (river banks) and all the world scriptures are in truth one and sing in unison the sweet message of love and concord, good ness and kindness, service and worship" (Sivananda 1980, 74-5). 
His vision was that the message of the Upanishads would permeate the land and dharma would be cultivated in every walk of life. Sivananda's firm belief was that man was divine in nature and that the Vedas, Upanishads, the Bhagavad Gita, known as the prasthanatrayi would allow mankind achieve moksha, or freedom and exist beyond karma-samsara, or action and the world process (Gyan 144, Sivananda 1980, 7).

Regarding the term Hinduism itself, Sivananda states:

Hinduism allows absolute freedom to the rational mind of man...It allows everybody to reflect, investigate, enquire and cognate...Hinduism does not condemn those who deny God as the Creator and Ruler of the world. Hinduism prescribes graded series of different Yoga Sadhana to suit students of different states, temperaments and capacities, and of different stages of spiritual development and different conditions of life. Religion is spiritualization of human life for a Hindu (Sivananda 1947 2-5).

\section{Sivananda's Analysis of the Guru and Disciple Relationship}

Having provided a synopsis of Sivananda's teaching philosophy, I now introduce the topic of the guru and disciple relationship as informed by Sivananda. It is interesting to note that though Sivananda has dedicated much literature devoted to the guru relationship, and was seen as a guru and even an avatar in his time, he denounced any such titles and status.

I am not pleased when people call me 'Sat guru' or 'avatar.' I am dead against gurudom. That is a great obstacle and has caused the downfall of great men in the spiritual path. Gurudom is a menace to society...In 1933 the publishers in Madras wrote articles on my life and mentioned me as an 'avatar.' Immediately I gave a reply which explains the attitude I have always maintained: 'Kindly remove all 'Krishna Avatar' and 'Bhagavan' business (Baird 90). 
In Gyana Yoga, he writes,

A Jivanmukta or sad-guru is a blessing to the world. He is a spiritual lighthouse to shed light to those who move in the ocean of ignorance. He is identical with Brahman or the supreme Self. He is a Brahmavid or knower of Brahman...He is extremely humble. He appears to be quite an ordinary man (Sivananda 1947, 8). A sad guru is absolutely free from passion, anger, selfishness, greed, hatred and egoism...He is able to remove the ignorance of people. He can clear any kind of doubt. He can give practical, easy lessons to control the mind and the senses. His instructions are very impressive (11).

The depths of descriptions given in Swami Sivananda's works would seem boundless to the reader, and with this we also find the description of the adhikari, or the qualified student. The student of the guru ultimately seeks to attain such a knowledge that would grant them immortality and are required to possess faith, devotion, selfrestraint, one-pointedness of mind, purity of heart, dispassion and desire for liberation. The guru in turn seeing these characteristics within the adhikari will only then impart spiritual instructions (12). For one to become a disciple of a guru, they must obtain initiation. Swami Sivananda discusses that formal initiations are not necessary and even having a mere thought of a divine personality is initiation.

Furthermore, initiation can occur though books, letters, and the will of the Master. The process of initiation is different for each spiritual aspirant and arises according to a divine plan (14). "Initiation, inspiration and the attainment of knowledge depend upon the aspirant's personal efforts and his earnestness (15)." For an aspirant to be initiated there must be a complete synergy between the guru and disciple. They have the most intimate of relationships where each understands the nature of the other completely. The student must possess the knowledge of the high ideals taught and exemplified by the 
guru, and the guru in return must be able to detect the inner working of the student's mind and be able to correct any deviations along the path (18).

The student being equipped with all of the qualifications of an adhikari, engaging in the study of the Vedas, and performing seva (service) to the guru and thier ashram must also fully identify himself with the guru. The student is one who embodies the teachings of the guru but also as if mimics the guru so as to become or share an intimate identity with the guru (19). Though Sivananda highlights the importance of the guru extensively, simply having a guru does not secure realization. He writes:

Guru's grace is needed by the disciple. This does not mean that the disciple should sit idle and expect a miracle from the guru to push him directly into Samadhi. The guru cannot do Sadhana for the student...The guru can guide the student, clear his doubts, pave the way, remove the snares, pitfalls and obstacles, and throw light on the path. But it is the disciple himself who has to walk every step in the spiritual path (Sivananda 1980, 25).

Additionally, just as it is important for the disciple to find a qualified Brahmavid guru, it may even be more important for the guru to find a qualified disciple. Sivananda expresses his opinion that disciples are many, but to find one who will be sincere and carry out the instructions of the guru is a "very, very difficult task (124)." He explains the problem is many disciples want to become gurus themselves without proper discipline and training and become arrogant. Therefore, Sivananda's mission as it relates to training his disciples is taken very seriously. He states:

Even if one of my disciples lifts up his head from the quagmire of Samsara (world process), I have justified my existence. The greatest service that I can do to humanity is training and molding aspirants. Every yogic student, when he is purified and elevated, becomes a center of spirituality. He will draw to himself, through his magnetic aura, thousands of baby souls for spiritual transformation and regeneration (125). 
Through the life and teachings of Sivananda it is understood how this monk embodied his own definition of 'guru' as well as the scholarly definitions previously elucidated. His teachings influenced his followers to gain independence in their spiritual path and transcend the level of discipleship by becoming "one" with the guru as they emulated the mission of Sivananda.

I now present the findings of the first interview I conducted for this ethnography. Swami Jyotirmayananda Saraswati, stands as one of the last remaining direct disciples of the Sivananda lineage and has established his own ashram in Miami, Florida for the purpose of continuing in Sivananda's mission of dissemination of Hindu spirituality.

\section{Swami Jyotirmayananda's Account of Swami Sivananda}

As a disciple of many years, I have observed that rarely does Swami Jyotirmayananda speak of his guru and when asked about him, often answers in an evasive and highly metaphorical manner often times leaving the questioner in wonderment. However, on isolated occasions he speaks of Sivananda and in his early writings we find several poems dedicated to his guru inform his ideals on guru and discipleship. The dates of when Jyotirmayananda has written these poems are not clear, and are speculated to be during the 1960s. These poems are eighteen in number and appear as part of a manuscript that forms the unpublished biography of Jyotirmayananda. With the permission of the editor, I share these works not in their entirety but in select verses that are specific to Sivananda as guru.

"The Thief and the Heartless Hunter"

Some extol my guru as a realized Sage. 
Some speak of him as Lord incarnate.

Some say he is Siva Himself.

Some say he is Buddha reborn.

Others, yet, speak of him in different ways.

But Jyotirmaya sayeth, "He is at best a thief,

Who has stolen my heart away.

Or I may call him a heartless hunter

To whom my heart is an animal of prey...

Give Me This Boon

Sayeth Jyotirmaya, "O My Lord Sivananda!"

Mayst thou grant this boon to me:

One alone its craving be

In silence to commune with thee.

"Oh Mind"

....Then, $\mathrm{O}$ my noble mind,

Cherish the Lotus Feet of my guru,

The sage Sivananda, my Lord and Life....

"A Drop in the Ocean"

"Remove my pain,

O my revered Master."

Desiring thus Jyotirmaya approached his Lord,

Sivananda, his dearest sage....

"Let Not"

O my Satguru, Sivananda the Sage,

My life, my light, my sole refuge,

Salutations and prostrations unto thee

.... Let not my heart be tired of communing with thee;

So says Jyotirmayananda.

"When Oh When"

...Losing my little individuality

Unto thy supreme personality?

Sayeth Jyotirmaya,

When, $\mathrm{O}$ when shall I be,

O Sivananda, one and one alone with thee?

"The Only Way"

...Sayeth Jyotirmaya, the guru's Lotus Feet alone

Are the way-safest, surest and best. 
During our interviews Swami Jyotirmayananda spoke of Swami Sivananda with high regards, explaining that he was recognized as "a luminary in his time and the present generation is extremely benefited by him and blessed by his presence...the teachings that came down through ancient times were filtered, purified and re-energized by Swami Sivananda."

Swami Sivananda himself grew up in a culture where he was inspired by what was happening in his country. He met Ramana Maharshi and saints of his time and he himself was initiated by a great sanyasi. The entire culture of spirituality was filtered in his mind - the teachings of Vivekananda, Ramakrishna Parmahansa, and teachings of those who have gone before him, he was well aware of them and studied all of them. Therefore, when teachings blossomed through him, the glory comes from all the generations before.

Direct teaching from Sivananda was not part of his style and as Jyotirmayananda explained, if a student wanted to learn a particular text, Sivananda would instruct him to "take the book and come to satsanga and talk about it," after which the disciple would be expected to deliver a public discourse on thier respective topic. If errors were made in delivery, Sivananda would correct the disciple's understanding during their lecture. Jyotirmayananda recounts that whether the discourse was intelligent or dull in nature, the public expressed appreciation and enjoyment.

Developing the inherent talents of disciples was another mode of instruction for Sivananda, as his philosophy was that "perfection comes gradually." Once an individual began to enjoy the teaching aspect of scripture, shastra and guru kripa, the grace of scripture and of the guru were said to follow, highlighting this being the core difference between "academic and spiritual study." 
A disciple several years ago requested Jyotirmayananda to share his favorite memory of Sivananda, in which his response was a loud crack of laughter followed by, "ask anything else because this is like asking me how to describe a cloud." The disciple then asked him to speak on a specific teaching of Sivananda he found most impactful:

Practicality, his teaching was that an ounce of practice is worth more than a ton of theory. Many gurus adhered to the tradition of keeping their disciples completely separated from society and instruct them to occupy themselves with various types of meditation from morning till night and being completely aloof of the world outside. But Swami Sivananda gave a twist to this; everyone had to follow a prescribed set of activities that would help themselves as well as others within the ashram; the ashram had its own project of disseminating spiritual knowledge. In this way he encouraged everyone to be extremely active and involved in their capabilities. An active movement allows you to practice yoga more profoundly. Flowing in a creative way - Serve, love meditate and realize was the teaching (Jyotirmayananda).

\section{Discussion}

Sivananda, the doctor of Malaysia became not only known for his medical achievement and philanthropic works in the field of healthcare but as guru who worked for the revitalization of Hindu thought and culture during a time where social issues, reform, and questioning of political power were highest. Sivananda along with his contemporaries during the Hindu Renaissance urged Indians to combat western ideals and thinking through seeking solutions found within their Vedic roots. The movement of the Divine Life Society stands as a leader for its mass dissemination of knowledge, through which the extension of Hindu scriptures were made assessable to laity, women, outcastes and children. Gyan's research discusses that the deliverance of Vedic tradition built a youth that was intellectual, rational and disputed unjust issues such as sati, child marriage, caste discrimination, and untouchability which were prevalent at the time 
(Gyan 80). Swami Sivananda can be recognized as a pioneer guru through lens of his disciples in how they continued his message on a grander scale, spreading to the West.

Furthermore, through the extensive writings of Sivananda along with the firsthand accounts of his disciple Jyotirmayananda, a clear characterization of the guru and disciple relationship and the pedagogical style of Sivananda are gleaned. Sivananda was a guru who did not adhere to traditional roles in his teaching style and organization of his ashram. In this way, the movement of Sivananda along with contemporaries of his time contributed to the revitalization of Hindu spirituality. Close study of the institutional organization of his direct disciple Swami Jyotirmayanda in Miami, Florida and his unique group of Western disciples inform how the transplantation of the guru and disciple relationship has further adapted and revitalized in the United States.

\section{Swami Jyotirmayananda - His Life and Teachings}

Little is known about the life of Swami Jyotirmayananda and upon inquiry the guru rarely answers direct questions regarding it, typically redirecting the attention of the questioner with humor. However through archival research of his birthday celebrations, his main lecture occasionally centers on events of his life. The life-sketch I present is derived from primary accounts from interviews with Jyotirmayananda, a brief biography printed on the back cover of his publications and the unpublished manuscript of his forthcoming biography written by Swami Lalitananda, his foremost Western disciple responsible for his migration to the West.

Born on February 3, 1931, Surendra was born to the parents Lakshmana Prasad and Rama-Sanehi in the village of Dumari Buzurg in the Bihar province of India. The 
ancestors of Surendra belong to the Bhagawanpur in the Muzaffarpur District of Bihar and moved to Dumari Buzurg in 1600 AD. His father, Lakshmana Prasad was a scholar in his own right in the fields of academia and religion. Surendra's entire family was devoted to the Hindu god, Rama and spent many hours weekly dedicated to the study of the Ramacharitramanas of Tulasidas, the Mahabharata and various other sacred texts.

Several miracles are reported to surround the life of Surendra. While still in the womb, his mother, Rama-Sanehi, suffered from a poisonous snake bite and both mother and child nearly died. After receiving medical attention from both her son Mahendra and the village physician, the entire village kept vigil with mantra-recitation until she regained her health and consciousness. When Surendra was finally born, he was lifeless and still born. Not crying for several hours, his mother was encouraged to discard the body. Rama-Sanehi engaged in prayer to the Hindu deity Shiva, for the life of her child and the infant began crying.

During his childhood another set of near death experiences are further reported. At the age of five, Surendra was seated next to the fire in the kitchen where his mother was cooking a pot of dhal, assisting her he began to stir the pot and in the process caught on fire. His entire body was in flames, his family tended to him with wet rags and he suffered second degree burns. The next devastating event occurred when he was playing in his home with his brother named Upendra. Due to poor ceiling construction, without notice bricks fell on Surendra's head deeply wounding him and leaving him unconscious in a pool of blood. A few days later after receiving medical attention, Surendra regained consciousness. In the midst of these experiences, Surendra spent most of his childhood extremely asthmatic and struggling and breathlessness was a daily occurrence. 
Both the childhood and adolescent years of Surrendra was spent in study of Hindu sacred texts and deep meditation. Being an excellent student, left him will ample free time to study the scriptures and even speaks today about hiding the Upanishads in his school books while pretending to read his text books. In his early adult years, Surendra left his village and traveled to Chabra and enrolled its university studying medicine. It was during this time that he read Mind-Its Mysteries and Control, a book authored by Swami Sivananda. Engaging in the techniques learned from this book, his practice no longer satisfied him and he withdrew from his university to meet Sivananda. He spent several days at the Sivananda ashram in Rishikesh and became inspired to become a disciple. Following the advice of Sivananda, he sought the permission of his parents and was conferred sanyas diksha at the age of 22 and renamed Swami Jyotirmayananda Saraswati.

His first task was to serve in the naturopathic clinic and then progressed further becoming a secretary of Sivananda, responsible for translating all his English books into Hindi. Amidst these duties Jyotirmayananda also taught as a resident professor of Vedanta at the Vedanta Forest Academy. During this time, an American lady by the name of Lenora Rego visited the ashram. After spending time at ashram and upon her wish, Sivananda initiated Lenora into sanyas and she was renamed Swami Lalitananda. Lalitananda became deeply inspired by the teachings of Jyotirmayananda and had daily lessons taught by him on Hindu scriptures (YRF Biography). It would be Swami Lalitananda who would later facilitate Jyotirmayananda's move to the west and help establish his career as a Yoga and Vedanta teacher. She also served as the vice president 
all Jyotirmayananda's organizations and founded many of her own. She attained mahasamadhi on February 17, 2013 in Miami, Florida.

In 1962 Swami Jyotirmayananda traveled to San Juan, Puerto Rico and founded the Sanatan Dharma Mandir, a platform established to disseminate Vedanta and Yoga in the form of lectures, classes and radio and television appearances in both English and Spanish. The institution of the Yoga Research Foundation was founded in 1969 in Miami, Florida along with sister branches existing in India, Africa and the United States. Within India, he runs the International Yoga Society and Jyotirmayananda ashram, Divya Jyoti grade school and the Lalita-Jyoti Anaathaalaya, an orphanage and school and several medical clinics (YRF 2013). The teachings, works and personal charisma of this Indian monk attracted many western disciples.

\section{The Ashram}

The ashram of Swami Jyotirmayananda is located within a neighborhood in South Miami in a location that is quite assessable yet so elusive that neighbors of the ashram may not even realize they are situated near a vibrant religious center. Upon entering are two white gates that lead one down a stony pathway, the left is the "workshop" that houses the printing press, and an office where disciples spend their time working on ashram correspondences, mail distribution and various administrative tasks. Attached to this is a doorway that leads into the main house and is the private residence of Jyotirmayananda. Generally only select disciples that tend to Jyotirmayananda's personal care can be found here. From the main gate, another path leads one toward the satsanga hall, followed by the extensive gardens that include a lake, a small lotus pond and several varieties of 
tropical fruit trees and lush greenery. Animal life is no less rich, as the ashram property was once an aviary, different species of birds are always present. In addition to the koi fish, the grounds inhabit turtles, rabbits, two dogs that are the pets of Jyotirmayanda, cats and the occasional monkey.

Prior to entering the main lecture hall, a room named "Ganesha Jyoti" is the designated area for the keeping of shoes, registration, contributing a donation and light chatter. The main hall, "Krishna" is where satsanga is conducted with Swami Jyotirmayananda. Almost immediately is one overwhelmed with the aroma of incense and the predominance of the color orange as it is used in every aspect of the décor to symbolize detachment. The standard greeting disciples use towards each other is " $\mathrm{Om}$ tat sat," and is explained as meaning, "God or pure consciousness alone is truth." The hall is the location of the Integral Yoga lecture series, meditation classes, private meetings with disciples and initiation ceremonies. The walls of the satsang hall feature prominent images of Hindu deities and figures from other traditions like Buddha, Jesus Christ, and Guru Nanak. 


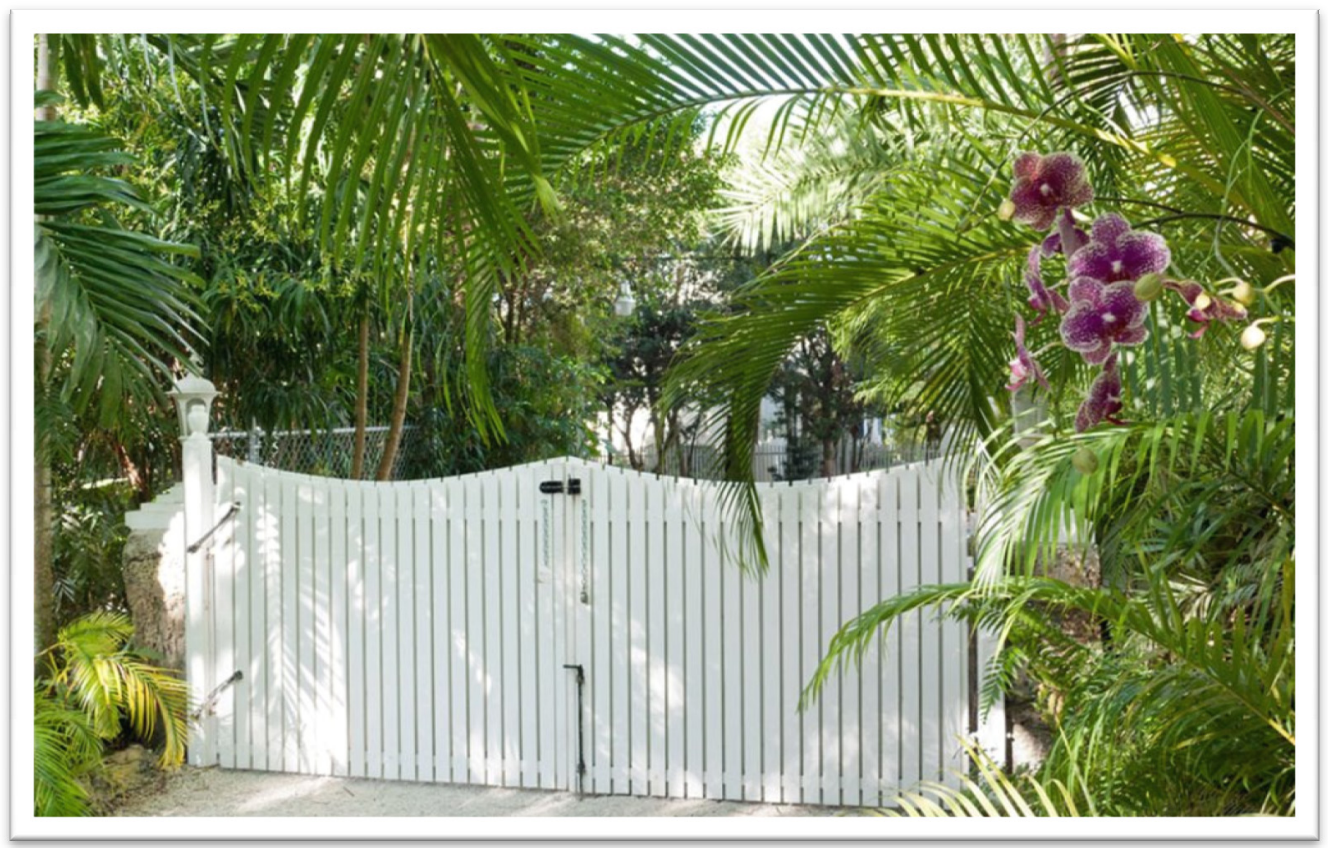

Figure 1 - Front gate of the Yoga Research Foundation

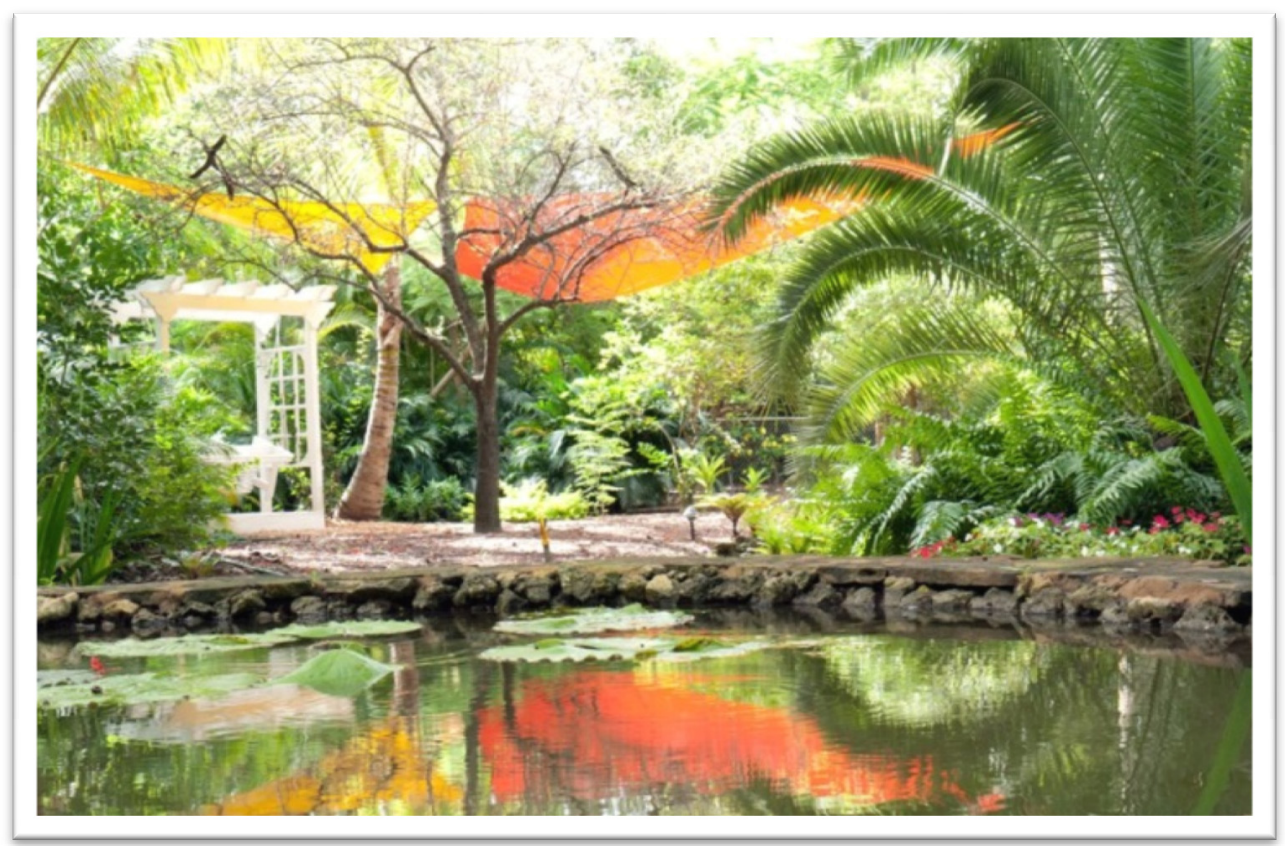

Figure 2 - Gardens of the Yoga Research Foundation 


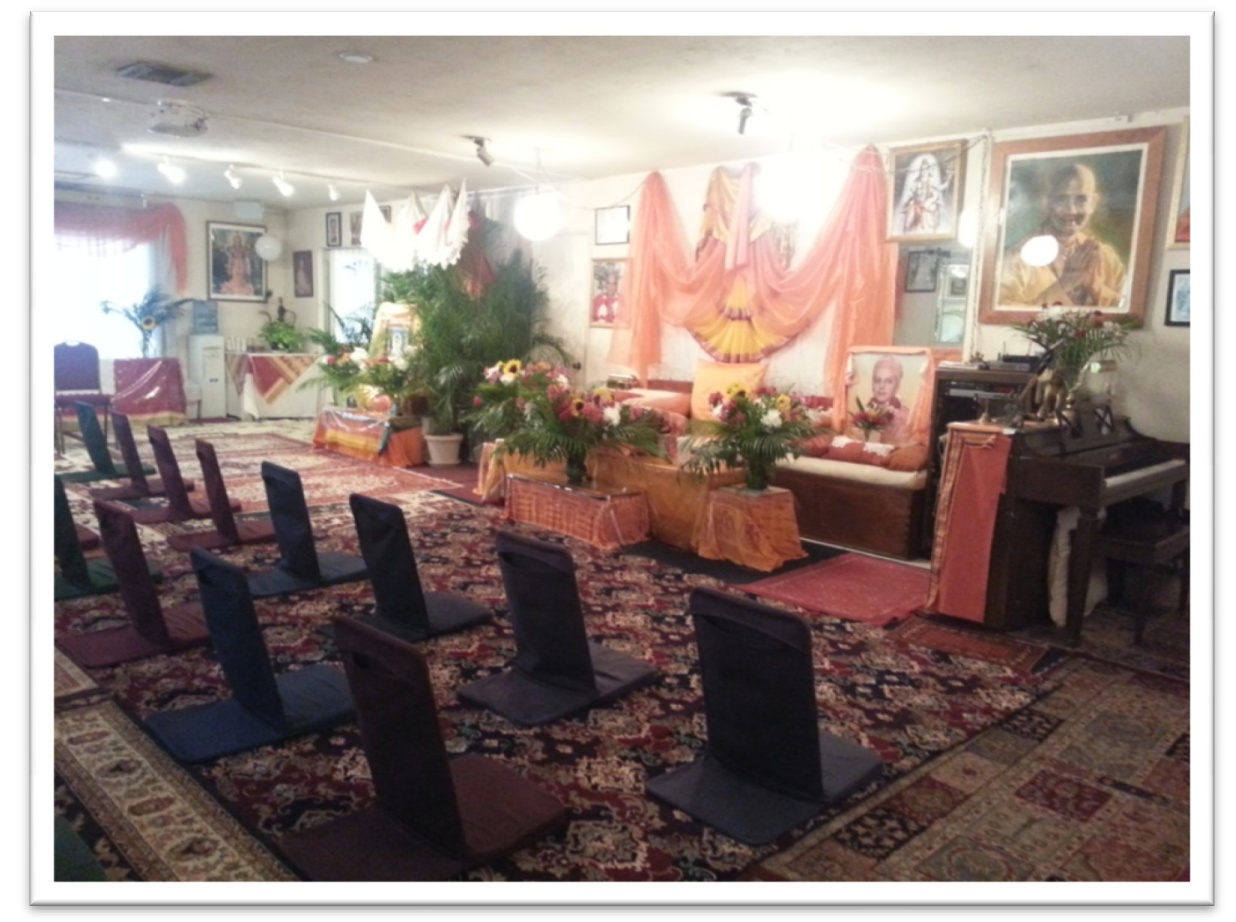

Figure 3 - Lecture Hall of the Yoga Research Foundation

\section{The Teachings of Jyotirmayananda}

Swami Jyotirmayananda teaches an adaptation of Yoga and Vedanta philosophy he terms as "Integral Yoga" exemplifying a resonance to Sivananda's "Yoga of Synthesis." Integral Yoga draws primarily from the core disciplines of karma, bhakti, gyana and raja yogas expounded upon in the Bhagavad Gita. From the onset of his book, Integral Yoga, Jyotirmayananda describes the origins of Yoga as one that cannot be claimed by any tradition or owned by group of persons just as Newton's law of gravity existed before Newton. The metaphor contributes to his larger discussion of spirituality and the futility in searching for its origins. He assumes a pragmatic approach where historical figures and dates are inferior in a disciples search for "self-perfection" (Jyotirmayananda 2009, 19). The self-perfection he speaks of is synonymous with the Sanskrit concept of 
moksha, referred to as self-realization. The goal of self-realization is described as one not confined to the tradition of Hinduism and its long line of avatars and religious teachers, as Jyotirmayananda states, "Christ, Buddha, Rama, Krishna, Moses and Muhammad all spoke of the possibility of rising beyond the narrow confines of the mind order to experience the joy and the expansion of peace by being reunited with the Divine Self within" (18). Regarding the "misconception about yoga in the West," Jyotrirmayananda expresses that it is not mere physical postures or a system of teachings designed to "achieve miracles" or "develop psychic powers," but a philosophy of "rational sequence" affording its student complete integration of personality (19).

Integral Yoga implies an understanding of Yoga in its completeness-an all-encompassing, all-aspected union with the Universal Self or God. In other words, an aspirant or Yogi must unite himself with God or the Absolute through every aspect of his personality-Action, Emotion, Will and Reason. In order to succeed, all these four must be cultivated in a balanced and integrated manner. Therefore, Integral Yoga presents a blend of four major Yogas corresponding to the four aspects of the human personality.

The first discipline of Karma Yoga (the yoga of action) corresponds to action and is used to "unfolds one's hidden potentialities while preparing one's psychological being" for the performance of daily action and the individual's alignment with "Divine Will." The second discipline of Bhakti Yoga (the yoga of devotion) relates to the "feeling" aspect of daily action and "brings about emotional integration." Raja Yoga (the yoga of meditation) are disciplines used to cultivate a "controlled mind," and are practices drawn from the Yoga Sutras of Patanjali (47). The final yoga, Jnana (the yoga of wisdom) develops an individual's reasoning capability (21). Disciplines such as hatha, kriya and nada yoga are regarded as minor and supplementary to the four major yogas within this 
context. Jyotirmayananda discusses that within Yoga philosophy significance can be drawn from day to day circumstances and ultimately the individual is the creator with his popular statement, "you are the architect of your own destiny." He then explains that both positive and negative experiences drawn into life are resultant of thinking patterns. Along with this teaching he promotes the active engagement in the world-process (samsara) rather than living a life of seclusion and renunciation as Indian monks are popularly portrayed (23).

The second major platform of Swami Jyotirmayananda's teachings is Vedanta. Vedanta as discussed earlier means "the end of the Vedas," is the final part of the Upanishads and comprise a body of teachings dedicated to non-dualistic Hindu thought. Jyotirmayananda defines the term Upanishad as 1) approaching God 2) sitting near the guru 3) mystery of the Self 4) destroyer of ignorance and 5) secret teaching. Regarding hearing the Upanishads from a guru, Jyotirmayananda writes:

The Upanishads are also known as shrutis or that which is to be heard. The revelations of the Sages have been handed down from guru to disciple since time immemorial in brief utterances. They must be heard from a qualified guru or preceptor, in order that they may be properly understood. One who has insight into the nature of the soul, one who is established in Self-realization, can interpret these Upanishads in the most effective manner.

Jyotirmayananda defines Vedanta's goal of moksha as "the establishment in the essential nature of the Self...freedom from birth and death" and the "attainment of immortality" that arises from one renouncing an identity with their ego (Jyotirmayananda 1978, 15).

Other texts regularly commented upon by Jyotirmayananda are the Yoga Vasisha, Mahabharata Vivekachoodamini, Raja Yoga Sutras, Ashtavakra Gita, Ramacharitramanas, and Srimad Bhagavatam. Satsanga, meaning good association, is a 
medium through which teachings are transferred from Jyotirmayananda to his disciples. Of satsanga he explains it allows the spiritual aspirant to "raise the level of though and feeling" in understanding the complex mind and highlights three major methods: "1) attending spiritual discourses conducted by advanced personalities 2) being guided by a spiritual guru 3) studying elevating literature" (Jyotirmayananda 1947, 13).

The promotion of prayer and japa or the recitation of a mantra is another major teaching of Jyotirmayananda as he defines these as the core methods to developing spiritual strength and overcoming mental affliction (14). Prayers within different religious traditions are enjoined through the collective chanting of "om Jesus Christ" and "om Buddha" on certain occasions along with his instruction that individuals worshipping different Gods are "in reality worshipping the same God" (Jyotirmayananda). Teaching Yoga and Vedanta through mythological stories, parables, anecdotes and humor, Jyotirmayananda focused on moderation and never extremism in a disciple's practice.

\section{Dissemination of "Integral Yoga"}

From an observational standpoint, the YRF's attitude toward the dissemination of Hindu teachings is ambitious as portrayed through the sheer amount of publications, continuous weekly lecture series, and free audio and video archives found on their official website.

Swami Jyotirmayananda has authored more than 50 books and pamphlets on topics on Upanishads, Yoga, Bhakti texts, Bhagavad Gita, Brahma Sutras as well as publications detailing advice to students and householders and parables for children. The YRF has an even more extensive collection of DVDs and audios as the majority of 
lectures are recorded. On a typical Saturday at the ashram, one would find devotees going through these archives and processing them to be available to the public. At this time, all books are being printed from a private local printer and in YRF's sister ashram in New Delhi. Prior to this, the ashram has its own printing press that was fully operational and was in use between 1970s and 1990s. The press still exists today as a historical momento of the ashram. During my interviews many disciples explained that Swami Jyotirmayananda was the first to learn how to use the press and then taught its operation to his disciples. The "International Yoga Guide (IYG)," YRF’s monthly magazine was printed on the ashram's press until 2006, upon which it was outsourced.

The IYG was transformed many times throughout YRF's history. In 1962, the first of these monthly magazines were titled "Sanatan Dharma," then in 1967 became "The Vision of Eternity" and finally the IYG became its official name is and still in circulation today. "Yoganjali," the Hindi version of the magazine is also widely circulated in India.

Lecture series within the YRF are ongoing throughout the year and accommodates the observance of Hindu, Buddhist and Christian religious holidays. Each of the five lectures per week center on a Hindu text, and the occasional "mysticism of the Bible" and excerpts from the Dhammapada. Lectures are structured to initially include a Sanskrit prayer and a classical style western bhajan (devotional songs) written by Swami Lalitananda that is sung and played on a piano by disciples. These songs were composed in English and often include Sanskrit mantras and feature Hindu deities and the quest of enlightenment as the subject of their lyrics. This song was is then followed by discourse and concluded with offered food (prasad) and a brief question and answer session. 
I depart as the researcher to mention that being a disciple of Swami Jyotirmayananda afforded me certain responsibilities that consisted of the editing of magazine articles, Sanskrit documents, transcription and also light chores such as cleaning the satsang hall and assisting to prepare food items in Jyotirmayananda's kitchen. Throughout the performance of these duties, I came to observe the guru in a way that could not be captured through an interview or traditional modalities of a researcher. For instance, the simplicity and extreme regularity of his lifestyle, availability given to disciples through personal meetings, initiation ceremonies and telephone calls, and the immense time the guru dedicated to responding to letters and emails from disciples in different parts of the world were all revealed through participant observation.

Most recently the ashram of Jyotirmayananda has also participated on social media forums of Facebook and Twitter, all projects commissioned by the guru. Every morning at 6:00AM followers of @SwamijiYRF can expect a tweet:

Let your every action be an act of worship of God. God is not limited to temples and churches alone. God is everywhere. He fills the earth and the Heavens. He sees through all eyes, and thinks through all minds (Facebook, 11/27/2013).

@SwamijiYRF: Grow in the image of God. Discover within yourself the Love of Christ, the Compassion of Buddha, the Bliss of Krishna! Blessings! Om! (12/19/2013).

@SwamijiYRF: Learn the art of divine detachment. Detach and Attach! Detach from the world of illusion and turn to God. Serve. Love. Mediate. Realize. OM. (12/20/2013).

Social media posts inform teachings of religious syncretism and also how Jyotirmayanda has adhered Sivananda's teachings, tweeting his popular quotes. 


\section{Swami Jyotirmayananda's Analysis of the Guru and Disciple Relationship}

The implications of the guru and disciple relationship as illustrated through archival research within publications and lectures and interviews with the guru all share a resonance to the researched understanding of Swami Sivananda. The core difference lies in Sivananda's use of Sanskrit terminology to describe the relationship, and Jyotirmayanda's de-emphasis of Sanskrit. These observed differences can be due to a distinction between predominantly Indian-Hindu audiences in India verses an American audience in the US.

Jyotirmayananda discusses that a guru must be a 1) brahmanishta, one who is established in Brahman and 2) a brahmashrotriya, one who is capable of explaining scriptural teachings. Jyotirmayananda further explains that a spiritual seeker is drawn to their guru according to the mysterious process of karma. The individual who does not have a direct access to their higher self needs and intermediary who is the guru, "thus by turning towards the guru, the aspirant is actually turning towards his higher self...the guru is like a bridge from the aspirants lesser plane of consciousness to the Divine Consciousness" (Jyotirmayananda 2009, 252).

The disciple never feels that he is away (from his guru)...physical distance does not matter much. A shishyas attunement is through the guru and then through the guru to God, therefore any good shishya becomes a representative of the guru and in the course of time he becomes the light. The basic purpose of the shishya is not to highlight the personality (of the guru), but highlight the teachings he wanted to give to the world. In that process a disciple can draw inspiration from all gurus without having a contradiction that he should not listen to another guru. And if the guru has passed away then a disciple is simply lost because he has already pledged not to have another guru (humor). This is all orthodoxy you see, and this is not in harmony with real scripture, Dattatreya had 24 gurus, and the entire universe around you is guru (Jyotirmayananda). 


\section{Disciple Interviews}

In this this section, I discuss the interview findings of Jyotirmayananda's disciples. A total of fifteen disciples were interviewed and I present the case studies of five disciples representative of a larger category: of 1) the initiated sanyasis 2) Catholic/Christian disciples 3) Jewish disciples 4) the Hindus and 5) the spiritual but not religious disciples. Each of these cases engages the issues of authority, religious transmission and identity surrounding the guru and disciple relationship.

\begin{tabular}{|c|c|c|c|c|}
\hline & Disciple & $\begin{array}{c}\text { Years of } \\
\text { Discipleship }\end{array}$ & Former Religious Identity & Present Religious Identity \\
\hline 1 & Ambika & $30+$ & None & Spiritual, non-religious \\
\hline 2 & Archana & $30+$ & Jewish & Neither spiritual nor religious \\
\hline 3 & Bhavani & $4+$ & Christian & Spiritual, non-religious \\
\hline 4 & Divyananda & $10+$ & Christian - Methodist & Hindu - religious, spiritual \\
\hline 5 & Maheshwari & & Catholic, Christian - Methodist & Hindu - religious, spiritual \\
\hline 6 & Padma Devi & $40+$ & Jewish & Spiritual, Jewish \\
\hline 7 & Prana & $35+$ & Catholic & $\begin{array}{l}\text { Spiritual, Vedantin, Catholic, non- } \\
\text { religious }\end{array}$ \\
\hline 8 & Radha & $5+$ & $\begin{array}{l}\text { Christian - Seventh Day } \\
\text { Adventist }\end{array}$ & Spiritual, Vedantin, non-religious \\
\hline 9 & Ramesh & $2+$ & Catholic & Spiritual, Catholic, non-religious \\
\hline 10 & Sankara & $5+$ & Catholic & Spiritual, non-religious \\
\hline 11 & Sharadananda & $3+$ & Catholic & Hindu - religious, spiritual \\
\hline 12 & Sri Arjuna & $35+$ & Christian & Hindu - religious, spiritual \\
\hline 13 & Sri Hari & $40+$ & Christian-Methodist & Spiritual, non-religious \\
\hline 14 & Mukunda & $2+$ & Catholic & Spiritual, Hindu, non-religious \\
\hline 15 & Vasudeva & $40+$ & None & Spiritual, non-religious \\
\hline
\end{tabular}

Figure 3 - Disciple Data

\section{The Western Sanyasis}

Within the last five years, Swami Jyotirmayananda has initiated two female disciples into 
the ancient order of sanyas, what is notable about these cases is the immense transformation of what it means to be a monastic in Jyotirmayananda lineage. The first case I present describes a more traditional adherence to the role of a sanyasi and the second a modern adaptation.

Swami Divyananda Saraswati first became aware of the teachings of Swami Jyotirmayananda through teaching with his literature during her tenure as a "balvihar" or youth teacher at the South Florida Hindu temple. Swami Divyananda, had no structured religious teaching during her childhood with the exception of limited visits to a Methodist church. Later in life she studied Hinduism under the Vedanta school of teachings for many years and made several pilgrimages to India prior to meeting Swami Jyotirmayananda. Her first meeting took place in 2001 where she asked for Jyotirmayananda's blessings and counsel on teaching his texts and then soon arranged for field trips to take her students to meet the "author of their text book". She recalls, "He had the unmistakable qualities of a divine person, the peace, the radiance, everything about him was just inviting, approachable, beautiful." Describing the qualities of a guru she explained:

To be a guru one must have attained the goal him or herself, and that goal is self-realization. There can be many teachers, but the gurus are not growing on trees...there aren't many teachers. To be a disciple means one has accepted the teachings transmitted by and through the guru and lives them to the best of their ability. It takes practice of the teachings and the study of the Vedas for one to be a guru.

Divyanananda described the transmission of the guru occurs in many different forms, the spiritual knowledge is transferred from the guru parampara and that is handed down from the guru to the disciple. Those who have taken initiation under Swami 
Jyotirmayananda belong to a certain lineage which goes back to Adi Sankara Acharya and even prior to him. "Swami Jyotirmayananda belongs to a very ancient and very traditional lineage that is entrusted with the spiritual trust to maintain the scholarship of the Vedas, and this is the Shringeri math." Of transmission she explains that it is highly dependent upon the student to understand the knowledge that is being transmitted. "It happens in the heart," different needs attract disciples to Jyotirmayananda, and there are certainly physical obstacles in finding his ashram, it more like a forest ashram in the middle of a thriving city, therefore people who find him find it difficult to "reason out" why they keep coming back or even not returning, "it's an interesting phenomenon to observe."

She recalls that Swamiji once told her students that "you can think of us as your grandparents," speaking of himself and Swami Lalitananda, explaining that the guru meets his devotee at their level in an approachable way. Further discussing that he innately understands seekers and what they are seeking on all spectrums and responds to each devotee accordingly.

With respect to reverential touching of the feet ritual, Divyananda describes that it is an ancient Indian tradition of respecting elders and religious leaders.

The feet are the base of the person and also energy leaves the body through two different points - the top of the head and the bottom of the feet, so a tremendous amount of a person's energy leaves the body this way. It is actually called taking their blessing rather than touching their feet. You are taking physical and spiritual energy from that person because one you touch their feet you traditionally touch their head, symbolically it signifies the transfer of that blessing. 
She elaborates that this transference can occur through a gaze, through a hand, hasta masta diskha, placing the hand on the head, the raising of the guru's hand in the air and energy transmitted through the finger tips, through words, mantras.

Regarding the importance of the guru and disciple relationship she relayed that, "God lives in the guru and the guru lives in God and there is a direct connection...a shishya learns from the guru and has an obligation to live the teachings in the best way and to reflect.

It has been made so that I am part of the guru parampara, and this has been conferred through initiation with Swami Jyotirmayananda, to Swami Sivananda and back to Adi Sankara Acharya and to God. There is an unbroken, spiritual and traditional lineage... and anyone who goes to the ashram, reads the books, watches the webcasts and takes mantra diksha, they are all part of this parampara and perhaps in a less formal way but nonetheless connected.

Divyananda views her role in the lineage to as a distinct purpose that evolves every day, but primarily encompasses being aware of her "oneness - relationship with the divine."

\section{Sanyas Initiation}

Swami Divyananda was conferred sanyas diksha in 2008, "usually how it happens is that a disciple has to spend many years under their guru before they are even eligible for it, but I had made myself eligible for about twenty years prior." Her reasons as she explained them to me were direct- - "to devote my life to my spiritual practice and less and less of the world." To prepare for the initiation ceremony, Swami Divyananda chose to adhere to traditional ceremonies as it would be conducted in India. She spent a week engaging in purificatory havans and pujas with a priest of the Shringeri math at the Shiva 
Vishnu temple in Ft. Lauderdale. Her ritual ochre robes for wearing were blessed by this priest and then presented to Swami Jyotirmayananda during her final ceremony that culminated on Shivarathri day, a day dedicated to the worship of the Hindu god 'Shiva' and traditionally designated for sanyas initiation. She relayed that she was $99 \%$ sure of her decision, but the $1 \%$ continued to create anxiety, so she silently spoke to God "Oh Divine mother, am I just another crazy American woman?" and sought the prayer "if I am supposed to do this, please give me a sign and let that sign be that Swami Jyotirmayananda name her "Divyananda." When it came time for Swamiji to name her, he asked her, "What name are you going to take?" Though having a name in mind, she refused to name herself; the guru asked this question three times. She explained that on the third time, his "eyes were dancing with laughter, merriment and love and he was playing with me!" After she said "Divyananda," she soon found that Jyotirmayanda had written that name on a paper he had walked into the initiation hall with prior. "Swamiji knew the vibration of my thoughts and was aware of them on a higher level and what I was going through...this is through great intuition cultivated through many hours, years, and decades of meditation." Divyananda described, "Names are based upon qualities that you have or qualities that you aspire to attain, for instance if you have a problem with anger, maybe your name might be shantananda (one who revels in peace)." Divyananda often feels that Swami Jyotirmayananda speaks publically during lecture specifically to her. Siddhis or supernatural abilities gained through spiritual disciplines were further explained. "I have observed him to have extraordinary patience, escape the neighbors may not appreciate the foot traffic in the neighborhood, and intuitively be able to know the state of mind of his disciples and exactly what they need" (Divyananda). 
The second sanyasi, Swami Sharadananda Saraswati or Dr. Reverend Grace as she is more widely known was initiated into mantra diksha in 2008 and was then initiated into sanyasa on her fiftieth birthday by Swami Jyotirmayananda. She is a professor of criminal justice, sociology and social work, a reverend and ordained interfaith minister and describes herself as a sanyasi and a disciple. Raised Catholic, Dr. Grace fully identifies herself as a Hindu and a baptized Catholic and draws upon several religious traditions within her personal spirituality and teaching her religious community.

Dr. Grace describes the life events that brought her to the ashram as extremely significant and even as preparation for the adoption of such a lifestyle. At this time, Dr. Grace was a retired lutenant of the NYPD after twenty years of service and was working on 9/11 relief projects. She experienced extreme exhaustion and the toil of her service coupled with her already growing depression, anxiousness and "physical and psychological ailments," and self-medication with alcohol and prescription medication was affecting her health.

With divine grace I felt moved to transform and do something that was completely different...this came through a twelve step program. They kept talking about a spiritual guide or director and I remember three months into this thinking please God send me this person.

Working on a film for the university she was employed brought her to Davie, Florida where she happened to find a Hindu temple and met a woman who would later introduce her to Swami Jyotirmayananda. Upon taking initiation, she described herself as being extremely nervous and unsure of the decision she was making. Dr. Grace, who was in a committed relationship with her partner of 15 years and the head of household was concerned about renouncing her relationship and career, adopting a vegetarian diet and 
wearing monastic robes. Jyotirmayananda reassured, “you don’t live in India and are not in a traditional environment, there are no cultural pressures here, your path is spiritual in nature, not fundamentalist." With response to how her guru guided her, Dr. Grace remarked, "I feel like he is Jesus and sees right through your soul and knows exactly what is for you at this moment."

Identifying with the stories of Hindu gods and goddesses operate in vital way in the life of Dr. Grace. "I am Rama, and Hanuman and Shiva, and here's why..." Dr. Grace described her story of as a homosexual female being raised in a strict Catholic environment and finding no reconciliation in her family and religion, she was forced to leave home as a teenager. This "exile" as she described was healed decades later when she learned the story of Rama, the Hindu god protagonist of the Ramayana and his exile (Sharadananda 2013).

With regards to the initiation process, she accepts the adoption of a new name as a form of commitment to a new path and a memory marking her change in consciousness. Dr. Grace operates a satellite of the YRF ashram under the name "Darshan Center" where she conducts lectures, officiates Hindu rituals (pujas) and Sanskrit prayers, kirtan (Hindu devotional songs) and mantra initiations similar to Jyotirmayananda's style. Texts she studies and lectures upon include the Bhagavad Gita, Vivekachoodamini, Yoga Vasisha and Narad Bhakti Sutras. As an accomplished musician, a large part of her services involve musical pieces in Sanskrit and English that are kirtan-inspired with folk, jazz and indie elements (Sharadananda). 


\section{Discussion}

For a disciple, sanyas marks the final phase of withdrawal from material life that embraces renunciation and dedication to a set of practices devoted to spiritual discipline for the achievement of moksa or liberation (Flood 13). Both Divyananda and Sharadananda conveyed an intense desire to take sanyas initiation even though each had major doubts. Within these cases, it is observed that a complete transformation of the visual of sanyasa has occurred while its function is still retained. Jyotirmayananda explained that a sanyasi has no social outlet within the United States and lacks the economic support to survive whereas in India, where society has fully accepts and facilitates the renunciate lifestyle. Both Divyananda and Sharadananda continue to maintain their status of employment understanding the impracticality of renouncing their careers. Furthermore, while Diyananda adheres to the status of single, Sharadananda was given no instruction from Jyotirmayananda that she need to renounce her partner or aspects of her life as a householder in any way. With regards to the traditional wearing of ochre robes, Jyotirmayananda made mention that this was not a necessary component of sanyas. Nevertheless, while Divyananda wears ochre robes, Sharadananda chooses to carry an ochre charm on her person that is a personal symbol of her sanyasa. Overall, the interviews of Divyanadna and Sharadananda reveal how sanyas-hood within this lineage have significantly transformed to accommodate American culture.

\section{The "Better" Catholic}

Two subjects emerged from my research with great interest as each of them independent 
of another and unasked proclaimed that the study of Vedanta under the tutelage of Swami Jyotirmayananda made them a "better" Christian or Catholic. Here I present the case of Prana, a Catholic middle aged man originally from Columbia and a disciple of the guru for over thirty-five years.

Prana, a practicing Catholic was introduced to Swami Jyotirmayananda in 1979. During the early 70 s he had been initiated into the practice of yoga in his native country of Columbia, his name 'Prana' was conferred from an initiation prior to Jyotirmayananda's. His previous initiation was conducted at the Paramahansa Satyananda ashram, an affiliate of the Sivananda organization.

More than 30 years ago, traveling along Coral Way in Miami, he noticed a YRF sign that read, "You are the architect of your destiny." Several months afterwards he decided to search for YRF, however by this time it had moved locations. Without previous knowledge of this, he described how he drove directly to the new location instinctively knowing the way with every turn. "Never for a second did I think I was lost...I believed I was guided there by whatever it was that brought me to Swamiji, you can call it God." It wasn't until five years later that he realized the ashram had sold its property on Coral Way, and this was when he knew that Jyotirmayananda was his guru. "To this day, that (experience) was very meaningful to me because it meant that I was meant to be his disciple." His first impression of Swami Jyotirmayananda was that he was gentle and a Vedanta scholar. Not having engaged interest in Vedanta, Prana primarily attended the YRF for hatha yoga courses and gradually gained interest in the philosophy. With regards to his religion, he identifies himself to be a practicing Catholic, attending church services each week with his family and attributes his ability to be "a 
better Catholic" because of the Vedanta teachings of Jyotirmayananda. "It's part of our community and sense of belonging...I go for my family." He also remarked, "I am no more Christian than I am a Hindu, but my culture and community is Christian.” If one were to question his religion he would answer, "Catholic" rather than getting involved in ancillary conversation about faith. "I am spiritual and by no means religious, I love the rituals but I feel that religiousness is kindergarten...My spiritual goal is serenity."

I have been around Swamiji for thirty-five years and I have no doubt he is Enlightened, Swamiji is today what I saw thirty-five years ago, he is not struggling and figuring it out...Swamiji is not a fellow traveler.

Over the years I started listening to his teachings and little by little there became an evolution of my mind and I went through all the questions I had about the soul, its existence, karma, reincarnation... little by little all the questions were answered, but more so the questions ceased to exist.

Prana described that through his inward evolution, hatha yoga became less important as he naturally pursued the path of "meditation and gyana yoga." Even though previously initiated into mantra diksha by Swami Satyananda, Prana felt that his mantra was enhanced by the presence of Jyotirmayananda and his years of disciplship. He originally practiced mantra recitation with seed (beej) mantra consisting of a few syllables, of which Jyotirmayananda instructed him on its full version. "I have never had a formal initiation that others speak about coming here at 5:00 $\mathrm{AM}$ in the morning, nor do I need one, my connection with him is there already without it." The particular deity Prana's mantra is connected to is Rama and though engaging in regular practice, he does not hold a particular affinity to the god Rama with attributes, but rather to a formless consciousness or Brahman. "I am very western in my thinking and I do not have any connection with Rama or the Indian-ness of the ashram." 
The greatest form of transmission of knowledge Prana notes is Swamiji's teaching through example and through intellectual lectures, it is more about being in the presence of the guru because he is "true to his teachings and this could be observed during the death of Swami Lalitananda." "He has taught me more of marriage, without ever have been married just by observation in his dealings with others and his dealings with Swami Lalitananda." When I asked Prana what has kept him a regular attendee of the ashram for thirty five years he explained succinctly, "Because I know it is the truth and I know I am in the right place." Prana explained his years of doubting whether or not the ashram was the right place for him, as he was not Indian and culturally did not fit it and wondering the legitimacy of this religious group. "Whatever I have not accomplished, I know that it is here" (Prana).

\section{The Hindus}

Two subjects, one by the name of Sri Arjuna, an Anglo American male and the second, Maheshwari, a Haitian American female each affiliate themselves as members of the Hindu faith. In this segment of my ethnographic findings I present a brief narrative detailing Maheshwari's viewpoints on implications of the guru and disciple relationship. I chose to include Maheshwari's narrative as within her interview; though unasked she presented strong opinions of the purification of the Western world through Eastern ideology.

Maheshwari, an Interfaith minister was originally born in Haiti in 1947 and was raised in the Catholic and Methodist traditions and now identifies herself as Hindu through her involvement as a disciple of Swami Jyotirmayananda. First learning about Hinduism from her seminary studies, she became highly interested in its practices and 
philosophy. Maheswari was introduced to Jyotirmayanda in 2008 and received mantra initiation the following year. "At first I didn't understand much, but I kept on coming, I felt that Swamiji was an Enlightened person...a manifestation of God...and I felt his guidance...it resonated with me and gave me insights to learn more." During her initiation, she was offered two names to choose from and Jyotirmayananda asked her to choose one, because she was initiated with a Shiva deity mantra, she became "Maheshwari - great goddess" as Shiva is also referred to as "Mahesh." She recalls the name change was symbolic as it represented "positivity' and a new way of living life, and "I learned that liberation is something I can gain before I die." Hindu practices Maheshwari regularly engages in are meditation, reading of Hindu sacred texts like the Bhagavad Gita, chanting of Sanskrit mantras and simple forms of puja. "I consider that I am a Hindu, I feel I have a sense of belonging, I am more assertive now that I am a Hindu, and I realized that I have to share." Maheshwari discussed that she finds great affinity with Jyotirmayananda's teachings because he frequently teaches and draws references from the Bible. "The guru explains to us the true meaning of it. For a long time the Catholic people were not allowed to read the Bible, but thanks to my father who was Methodist he introduced the whole family to the Bible. The teaching of the Catholic religion did not feed my soul and I was searching." Maheshwari informed that she feels this is not Jyotirmayananda's first incarnation as he returns in different births for the duty of expounding Vedic teachings and that the West is extremely lucky to be in his presence. Comparing him to the Dalai Lama, she says "it is all about learning unconditional love." She elaborates on the Western world and why it needs greater purification due its materialism and lack of understanding the "oneness" between individuals. 
The West needs this teaching much more because it is very materialistic and they have the tendency to go to extremes in thinking their religion is the only way. But Truth never changes and they are not open to hear others. The West and the East are different in spiritual food, we eat every day, but how often do we really nourish our soul, in the West it is about making it and having this and that, but never thinking of the soul. It's all about the figures and the bottom line. I have been to India, and Westerners often think of Indians as poor people who live and die on the streets. But nevertheless they are much happier than the homeless here. I don't think the West is completely awakened (Maheshwari).

\section{Disciples of Jewish Background}

Out of the sample I collected, two females were raised with the Jewish faith, Padma Devi and Archana. Padma Devi a disciple of over forty years identifies herself as Jewish, whereas Archana, a disciple for more than thirty years identifies herself as neither spiritual nor religious. I group these disciples together in my description as their interviews yielded great similarities. Neither of these women claims great interest in the religiosity of their native religion of Judaism nor the Hinduism of the ashram, as they identify less with dogma and ritual and more with the philosophy of spirituality. Though Archana admits that she is neither spiritual nor religious she expressed greater comfort with identifying as one who is "cultivating sattwa (purity)," explaining that "there are so many wonderful people in the world who do not call themselves spiritual." Each of these women, though having pleasant experiences with Judaism in childhood, informed the Judaic concepts that seemed problematic were those of "we are the chosen people," and echoed a similar sentiment that its teachings did not go "deep enough."

Archana recalls that by 1974 she knew Jyotirmayananda was the person she wanted to study with, "by all definitions, Swamiji is my guru....it (the ashram) was open, it was healthy, it was moderate, it was warm, it just made complete sense to my heart and 
my mind." She described that a guru is someone that exemplifies the meaning of life and teaches others how to achieve that meaning. Jyotirmayananda's humor and approach to teaching the philosophy of life and dealing with the ego and negative aspects of one's personality is what resonated with Archana most as she frequently mentioned, "it was his words and the way he said them" that enthralled her. She spoke extensively of the humor in his style, and that it helped herself and other disciples laugh at issues they were experiencing, and offered a lightheartedness that prevented them from taking their circumstances too seriously. "Once he gets me to laugh at that burden, it is not that it is gone forever, but it is tremendously lightened...I enjoy his laughter blended with the depth of his teaching and it makes me feel like I can make sense out of my existence." Archana reflecting on the style of teaching she explained that Jyotirmayananda is not concerned with appearing or even sounding like a scholar or being dense or vague in his teachings in anyway, rather he speaks clearly, yet in highly colorful ways and "conveys the joy of Enlightenment" (Archana).

Both Padma Devi and Archana expressed similar viewpoints in not identifying as being a part of Jyotirmayananda's lineage, not engaging in any Hindu ritualistic phenomenon and deity worship. Each of them however engage in mantra recitation and expressed that they understand Integral Yoga as a separate philosophy outside of traditional religion. Padma explains that through the years of studying with Jyotirmayananda she has attuned herself to the degree that when she asks for guidance inwardly of "what would Swamiji do?" she receives an answer, and this is mostly how her guru affects her daily life. This sentiment was especially relevant when she discussed her three children, who are all of the Jewish faith and the patience she felt when raising 
them. It is interesting to note that her eldest son became extremely orthodox, living in Jerusalem for several years, and attributes his orthodoxy within Judaism to the Vedanta teachings he learned from Jyotirmayananda as a child. Padma herself engages in a life that is strongly colored by Judaic practices and Vedanta teachings. She describes her goal as to simply become closer to God that is universal and that is the same God that exists in the Hindu and Judaic faiths (Padma).

\section{The Spiritual but not Religious, and Mostly a Vedantist}

This segment of my ethnographic detail describes a female subject who participates in religious practices of both Christianity and Hinduism however does not describe herself as either. Identifying with strong reservations against religiousness, she is spiritual. Fourteen out the fifteen disciples interviewed also described themselves as such.

Radha an Anglo American, raised as an orthodox Seventh Day Adventist now identifies herself as an individual devoid of religion but who is "spiritual" and a "Vedantist." Having a long history in experimenting in and studying Eastern traditions, it was during her visit to India that she discovered the poetry of Sankara and found confirmation to the ideals she had intuitively believed in her entire life. At this juncture, she made a resolve to find a teacher whom she could study Vedanta with. Shortly after this trip in 2008 she met Jyotirmayananda in his ashram and instantaneously had the experience of knowing he was her guru and was initiated on her third visit to the ashram. She humorously described her initiation ceremony as being extremely lackluster in that it no way resembled the extravagant yagnas and pujas she experienced in India. However she was tremendously impressed by her name that was given as she had never studied the Hindu god of Radha. "I couldn't believe that he could intuit exactly who I was and what 
my level of devotion was. I was honored that he would recognize that bhakti in me...bhakti is in every fiber of my being." For Radha, the change of name behaved as a confirmation of the life she had lead and the goal that lay before her, recalling her highly religious upbringing. Radha regularly attends a Christian congregational church where she participates as soprano singer within the choir, along with attending regular ashram satsang. Most recently, she has relocated out of Miami and continues to stay involved with Jyotirmayananda's teachings through his webcast, emails, and visits to his ashram.

Having several experiences that she described under the title of "spiritual" and derived from "siddhis" gained through meditation and previous incarnations, she had never experienced a "teacher in embodiment" that could arrange all the pieces of her spiritual life in a way that she understood until the meeting of Jyotirmayananda.

With all these decades of mystical and spiritual experiences that I had and having visions from ascended Masters, it was like I had huge parts of a jigsaw puzzle already put together... and all I need was the box top so I couldn't see the big picture. Swamiji gave me the box top. Magically the puzzle came together.

Radha describes her relationship with the guru as one of great respect and admiration, and one where the questions she once had gradually drifted and left in its place was gratitude. Speaking on transmission between the guru and disciple, Radha offered insights and terminology that other subjects had not making her contribution unique and what I found insightfully dissected. She described several phenomenons of "shaktipat" as the primary modality of transference. "Shatipat is this ability to manipulate energy and by osmosis or the touching of someone, there is transference of energy. Though this energy transference of knowledge occurs, it can be through the raising of the kundalini...it consciously giving me spiritual knowledge and insight." 
The shaktipat can be received through a head tap where the guru places his hand on the disciple's head where the crown chakra is located, by being in his presence, listening to his teachings, reading his works and touching his feet. She notes that, "every time I touched his feet, I would offer a prayer that I could walk in his footsteps.” Viewing Jyotirmayananda as a figure of authority, Radha does not view Jyotirmayanda as an authoritarian personality, "it is because of his knowledge that I give him my undivided attention, so he does not demand it, I give it" (Radha).

In the next section of this chapter, I now analyze the data gathered on the organization, teachings and disciple accounts of the Sivananda and Jyotirmayananda's ashram through the lens of theoretical framework.

\section{Figure of Authority}

Gurus are often described as charismatic and this quality is possibly more valuable to the establishment of their order verses their own spiritual attainment. Within the field of social research, Weber constructed ideal types that generalize single traits common to a group (Pals 155). The traditional, legal and charismatic define the Webarian concept of authoritative types within society. As "pure charisma" is exclusive of social economics, it echoes a particular calling, a "mission or a spiritual duty" that is urgent (Weber, 1947 362):

"The term 'charisma' will be applied to a certain quality of an individual personality by virtue of which he is set apart from ordinary men and treated as endowed with supernatural, superhuman, or at least specifically exceptional powers or qualities. These are such as are not accessible to the ordinary person, but are regarded as of divine origin or as exemplary, and on the basis of them the individual concerned is treated as a leader" (359). 
Charismatic authority falls outside the realm of normal societal function and the "profane sphere," which separates it from both the rational and traditional roles of authority that are present in everyday routines (361). Often with the establishment of the charismatic leader the sustainability of the organization becomes problematic, Weber offers a solution as the community 1) searches for a new leader possessing specific charismatic qualities 2) through revelation such as that divinated through oracles or forms of divine judgments 3) through designation of the original leader 4) selection by the "charismatically qualified" staff and community authorization 5) through charisma inherited by heredity and finally 6) through ritualistic means (365-6). Routinization of charismatic organizations further requires its innately anti-economic structure to be modified into a form of fiscal institution so as to provide for the sustainability of the group (369).

My findings suggest that Swami Jyotirmayananda and his organization fit the classic Weberian definition of charismatic. His authority rests within a constant dialogic relation between himself and the disciple. Jyotirmayananda's authority as a religious figure in the US is based upon his credentials as a direct disciple of Sivananda, his personal charisma, as well as transforming the teachings of Yoga and Vedanta so as to appeal to an American audience. These credentials are authorizing discourses and his disciples imbue them with authority. The guru-disciple phenomenon is typically depicted as a power relationship in which the guru requires complete submission from the disciple in order to transmit knowledge (Baumer 347). However, within this lineage traditional models of this relationship are transforming, giving power to the disciple by granting a 
sense of autonomy in how they relate to their guru and how they carve out their spirituality.

Based upon my fieldwork, the source of the authority of Jyotirmayananda lies in a reciprocal relationship with his disciples. He has less of an ability to dictate, and his authority is dependent upon, how his disciples perceive his power. For example, in observation of the celebration of his recent birthday at his ashram, a Venezuelan born Catholic equated Jyotirmayananda's status to that of Jesus Christ; another American born Christian explained her understanding of Jyotirmayananda as an avatar of God, while others indicated that he plays a parental role in their life. During my interviews several disciples also remarked on Jyotirmayananda supernatural abilities, claiming that he had the power to read thoughts, spontaneously answer unasked questions of disciples during group lectures, see into disciples past lives and grant guidance through dreams (Arjuna, Ambika, Ramesh, Radha).

The themes of supernatural abilities associated with gurus are described by Betina Baumer:

The guru's knowledge, directed completely toward the spiritual reality, implies also his capacity to understand the disciple's thoughts and his level, which is obvious from the variety of answers. The same guru gives different answers to different disciples, and also to the same disciple at different moments, depending on the latter's development, state of mind and purity of intention. The capacity to read the disciple's thoughts was considered natural for a master and not a special siddhi (supernatural power) in later times (Baumer 343).

Furthermore, while Vedic rituals are not typically part of the ashram's routine, as Jyotirmayananda de-emphasizes their purpose, on the occasion of his birthday he conceded to his disciples' wish and allowed Hindu priests to perform rituals for his 
wellbeing and the traditional worship of his feet (padpuja). Despite Jyotirmayanda's refusal to accept any titles or claim a status as God, he allows his disciples the freedom to revere him according their own disposition.

Though Jyotirmayananda has established his following through charismatic leadership, it is a limited avenue for understanding his authority, as different negotiations are made with each disciple and the quality of his authority can only be derived based on the nature of each relationship.

\section{Succession Planning}

Through my observations and engagement with other disciples of the YRF ashram, the question of continuity and succession planning after the death, or as disciples would say, "is no longer physically here" is the constant point of inquiry and discussion. Due to discomfort, disciples typically refrain from asking this question in the presence of a wide audience, and resort to its discussion in smaller groups. During my interviews with the guru when asked about the future of YRF as his passing, Swami Jyotirmayanda hesitated for a few seconds and then released a crack of laughter. He admitted that he paused to think of a joke in response to my question but could not, all while continuing to chuckle. Becoming more serious in demeanor, he stated, "There is no voting system," and that though many may wonder what will happen to the "divine activity in the world", the mind of the guru does not involve itself with futuristic happenings.

The guru is not worried with that, it is not like a household process where you build a house and you are worried whether or not the next generation will recognize it so you lay down certain laws to restrict them. This might be fine I am not contradicting it. For the ashram, to an extent there is a monetary aspect and a plan of how things are etc. that follows certain 
politics. But there is no pressure in the mind of anybody of who will be the guru after; such a person comes from God you see.

From this answer, I could not deduce exactly where the seriousness of Swami Jyotirmayananda's answer existed. Judging from the informal conversations had with his disciples, the ashram will continue in its mission of dissemination of knowledge through the thousands of hours of lecture on audio and video, publishing of the monthly magazine and forthcoming works and perhaps a close disciple may even be charged with the task of continuing Jyotirmayanda's lecture series (Archana). Despite the future outcome, the guru seems cheerfully detached from succession planning and the continuity of his teaching tradition.

\section{Religious Transmission}

There are several methods by which disciples reported experiencing religious and spiritual transmission from the guru. Of all the methods described, none are as important as the initiation ceremony that behaves as an entry point for a disciple to experience subsequent forms of transmission. Though an individual may decide against the engagement of initiation rites, through sheer attendance they are expected to adhere to a set of predetermined rules governing this group as within the ashram gates, space is deemed sacred. I use the term "sacred" within the context of Durkheim's classical division of the world in two categories, sacred and profane, with the sacred "naturally considered superior in dignity and power to profane" (Durkheim 37). Initiation ceremonies within the YRF observably occur between 0-6 times per month and are one of the most vital ways disciples experience religious phenomena. Durkheim explains that religious phenomena are organically classified according to two 
processes of beliefs and rites. Its distinction lies in "the first are states of opinion, and consist in representations, the second are determined modes of action." Rites are separate from common human practices and can only be understood through beliefs that are classified according to the sacred and profane (Kunin 28).

To analyze the phenomena that occurs within the ashram and its group of disciples I engage Victor Turner's frameworking of the ritual process. Turner, drawing upon Van Gennep's three-tiered structure of ritual passage maps the liminal status during the religious transmission process, which is otherwise structurally invisible (Andrews 23, Gennep 21). Liminal personae, or "threshold people" are condition by an existence of ambiguity. Turner explains that liminal entities are "neither here nor there" and are characterized by "indeterminate attributes" consisting of symbols within a society that "ritualizes social and cultural transitions." Liminality is further interpreted by highs and lows, and each subphase is interdependent as one is incapable of gaining the experience of one without the presence of the other (Turner 1966, 95). Communitas defined as a "communion of equal individuals who submit together to the general authority of the ritual elders," emerges from the liminal period (96). Turner explains:

Communitus breaks in through the interstices of structure, in liminality; at the edge of structure, in marginality; and from beneath structure, in inferiority. It is almost everywhere held to be sacred or "holy," possibly because it transgresses or dissolves the norms that govern structured and institutionalized relationships and is accompanied by experiences of unprecedented potency (372).

For the disciples of Swami Jyotirmayananda, the liminal state exists in degrees from 1) pre-initiation 2) during initiation 3) post-initiation. 


\section{Pre-Initiation Rites}

Pre-initiation is conditioned by a state of crisis where an individual through their own volition is seeking an outlet of release. Several disciples reported the experience of extreme depression, the search for guidance, a teacher, a guru and the answers to lifelong questions. It is within this state, uninitiated disciples enter the ashram communitas. Specific rules exist that govern their interaction with the guru, the existing group and the space itself though unwritten and mostly unenforced. Prior to entry into the main lecture hall, shoes must be removed; this action is symbolically described as the removal of desires and attachments to material existence. Second, the individual must sign their name on the ashram's daily record and offer the suggested monetary donation. The third step must be taken into the main hall where silence is strictly enforced and the only sound to be heard is the occasional greeting of "Om tat sat" between individuals. Seating is arranged either on the floor or on chairs that line the back wall; each seat is directly positioned before of the guru's seat that is located in the front and center of the hall. The guru then enters through a door located to the left of hall and upon sight, all disciples and visitors must rise and greet the guru with a collective Sanskrit chant of, "Om namo narayana." At the conclusion of the teaching, as the guru stands from his seat, all are also expected to stand again as a sign of respect. The basic principle observed is if the guru stands, the group is also permitted to stand, and if he is seated, the group may also be seated. The final step is where the guru stands before the door he entered and waits as each individual forms a line to take his blessings one by one. Upon the departure of the guru, the group is permitted to disperse and engage in light chatter. 
These specific rules that govern group behavior did not always exist and have evolved over time. During interviews with disciples who have attended the ashram for more thirty years, report that these rituals were far less formal, except for the initiation ceremony which has remained intact. They attribute these changes to an Indian disciple who assumed administrative leadership of the ashram. Nevertheless each of these rituals serves to establish the creation of sacred space.

\section{Initiation Ceremony}

It is during the initial visitations to the ashram, that one develops the interest, makes the decision to request initiation and then must wait for the guru's approval. Once given approval, the individual is conferred initiation by the guru and accepts discipleship, thereby given a new name, a mantra corresponding to a Hindu deity that becomes the object of worship and various other disciplines prescribed by the guru. Disciples report that the initiation ceremony marked a change within their consciousness, a renewed commitment to the spiritual path and way of identifying themselves formally as a disciple of Jyotirmayananda, thereby becoming part of the Sankara lineage. Jyotirmayananda explains that though his disciples attribute great importance to the initiation ceremony itself, it is just an "encouragement" and the rituals are performed more for the individual and their inclination, and is not compulsory." Jyotirmayananda describes the concept of ashramas, the four stages within a Hindu's life:

1) brahmacharya ashrama: the student's life of discipline 2) grihasta ashrama: married and householder life 3) vanaprasta ashram: a life deeply involved in spirituality 4) sanyasa: life of renunciation completely devoted to spirituality. Initiation also serves a greater societal purpose as it is viewed upon with reverence. In a healthy society initiation is something that is looked upon with reverence, a sanyasi, even though he may not 
have gained higher perfection, for virtue of taking sanyasa, he becomes worshipful, and this helps others to exude goodness.

Two types of initiation ceremonies are conducted 1) mantra initiation and 2) sanyas initiation, in each ritual disciples are given a new name and a mantra. Jyotirmayananda explains:

Mantras can be given to a person belonging to any ashrama and gives a person the very foundation upon which they can work on spiritual advancement. Nama smarana is directing the mind to the glory of the divine name and is the simplest of all teachings and the most vital because it impresses in your mind a relationship with god. A mantra already has great associations, as it has come down through history it gains a potency that has a mystical effect on the mind. There exists a profound science on the power of Sanskrit syllables.

The naming process and the selection of the deity are critical to the initiation process. Jyotirmayananda informs that the name allows one to withdraw themselves of from their previous associations and the deity, "a manifestation of God" helps to allows this process to occur. Jyotirmayananda allows the disciple the autonomy to inform their inclinations toward a particular name and deity. This becomes especially important if an initiate has a prior history of worshipping a particular deity as continuity of worship is preferred by the guru.

In my style people who come already have some experience, so they are presented with a choice. If they say they want a Krishna or Shiva mantra, I will not object to that because mantras are the same God in different aspects. In the same way if you are invited by a host and you say, "I don't like cauliflower", that's ok they will give you potatoes. The same idea is given that you should not be distracted and go on changing your mantra because they all have the same potency and describe the same god. The same devata is Jesus and Buddha, therefore your mind feels the same joy when you chant these names. Many people receive mantra initiation from me for Lord Jesus. I have initiated disciples in to the mantra, "Om Jesus, Jesus Christ" If they (disciples) come I will initiate them according to their own disposition, like "om mani padme hum" (Jyotirmayananda). 


\section{Post Initiation and Transference}

My researched findings suggest that the initiation ceremony followed by a disciples adherence to the prescribed discipline of mantra recitation, engagement in satsanga and study of scripture facilitates the transmission of knowledge between the guru and disciple. Mantra behaves as a purificatory rite that continues throughout the life of the initiate simultaneous to experience of knowledge. With regards to where knowledge occurs Jyotirmayananda states:

It is in the mind. It is the mind that is trying to bring to you the aroma of pleasure and pain, of past and future, and the entire world process. When you analyze the mind it has four aspects: intellect, mind, ego, mind-stuff (chitta). All your illusions are based upon the four fold mind, and among these equipments, the intellect plays the greatest part. In other words, the end result of your spiritual movement impacts intellect the most and that impact means that the intellect is no longer under the clutches of the ego. This brings about a broader understanding of "who am I?" as your intellect allows you to move away from narrow minded concepts. Then aham brahmasi (I am Brahman), is revealed by the intellect. The intellect undergoes a transformation from the rational aspect to the intuitional aspect. Chakshurunmilitam yena - the opening the real eyes. (Jyotirmayananda).

The final stage within the liminal state is one conditioned by the disciple's constant pursuit of effacement of the ego culminating in the ascertainment of knowledge. The liminal state of an individual continues until they attain release or moksha through the freedom of knowledge. The guru discusses this can occur through the course of lifetimes until the intellect is able to intuitively understand its relationship with Brahman. The entire liminal state from its inception of the state of chaos to initiation, then reintegration into society is one where the individual is undergoing the Vedantic seeking of identity. 


\section{Identity}

My study reveals that a disciple's negotiation of identity is based upon the perceived authority of the guru and the simultaneous experience of religious transmission. The more power the disciple imbues upon the guru, the greater the transmission experienced correlating to stronger sense of identity as a disciple. The concept of "identity" varies within different disciples, Erik Erikson blending definitions from the disciplines of psychology and anthropology posits, 'the term 'identity' expresses such a mutual relation in that it connotes both a persistent sameness within oneself (selfsameness) and a persistent sharing of some kind of essential characteristics with others"' (Sokefeld, 417). Data derived from disciple interviews informed that the majority of disciples identify themselves as "spiritual but not religious." In understanding the rapidly increasing spirituality of Americans in the United States, it is important to define spirituality. The study of Gall et al concludes that spirituality "provides the framework for understanding and approaching daily life" and involves a lens by which individuals interact with themselves, others and the world (Gall et al 166).

Robert Fuller reports that $40 \%$ of all Americans though sharing an "unchurched status" believe themselves to be "deeply religious or spiritual on a personal level (Fuller 1)." Fuller states that the unchurched status is transforming major religious organizations as elements of occult religion are impressing upon mainstream religiosity (9). Of the growing trend of global spirituality, Nathan Katz discusses that ten years ago the category of being "spiritual but not religious" was non-existent. He contributes this rapidly growing group to the mainstream introduction of cosmological physics theory of the "God particle." Katz further contends that the introduction of spirituality in mainstream 
religiosity is predicated upon three main grounds: 1) historical 2) psychological 3)

findings within earth science. For the purpose of my argument I focus on the historical import of spirituality in the United States. Historically, Yoga as discussed in chapter two is one of the six systems of classical Hindu thought, and with the mass export of yoga and Vedanta in the US over a century ago became re-branded and popularized as a practice bereft of its religious context. Along with yoga, mystical and esoteric practices from Islam, Buddhism and Judaism also became secularized contributing to the "spiritual but not religious" label (Katz).

\section{Diaspora}

Disciples of Swami Jyotirmayananda of regular attendance at his ashram in Miami are primarily of Latin, Anglo-American, Caribbean and African descent. This study led me to consider the diasporic undercurrents within this multicultural community in determining what factors contribute to the sustainability of this group who have no direct connection to Hindu teachings or India as their homeland.

Diaspora classically "refers to the doubled relationship or dual loyalty that migrants, exiles and refugees have to places" (Lavie and Swedenburg 14). Khachig Toloyan advances the contemporary understanding of diasporicity explaining that it "manifests itself in relations of difference" departing from the classical conditioning of a peoples dispersal through catastrophic events. Within these instances, the host land is the home of diaspora communities as they are connected to the peoples of their home yet experience a cultural distinction from them (Tololyan 650). Diasporic populations experience further transformations within the US as it is a melting pot of multiculturalism 
and particularly in Miami, a metropolitan city that seems to exist apart from the norms of the US with regards to its demographics, language and culture (Haller and Landolt 1184). Therefore redefining new religo-spiritual identities within Miami's diasporic groups has further implications.

My data reflects that Jyotirmayananda's Western disciples are searching for answers without the rigidity of religious dogma that may have conditioned their upbringing within their homeland. The teachings of Yoga and Vedanta are diasporically resonant as it directs the disciple's attention to the empirical understanding of 'self' irrespective of racial and religious identities. During my disciple interviews, when asked if a disciple believes that Swami Jyotirmayananda is God, all fifteen disciples reported "yes" and qualified their answer by stating every individual is God. In this way there lies an appeal to Jyotirmayananda's teachings as it promotes an identity that is raised to the status of God-hood, leaving behind a transitory human existence. 


\section{CHAPTER 5 CONCLUSION}

The guru in the Hindu tradition describes the exalted state of the "master, teacher, spiritual guide and father" combined in to one individual who instills discipline in a disciple resulting in the realization of an Absolute Reality (Baumer 341). A vast history of literature from the Vedic period to present day commentaries exist supporting the authority of the guru, arguing knowledge cannot be ascertained through an individual's efforts alone, there must be guidance. Hinduism in her many permutations have recreated itself throughout history particularly due to Indian invasions that brought new religions into India and through globalization.

Presently, traditions of contemporary Hinduism are "constantly being reinvented, yet at the same time maintaining continuity with the past" (Jacobs 129). My study focused on the transitioning nature of the guru and disciple tradition in the US through the movement, the Yoga Research Foundation founded by the contemporary guru, Swami Jyotirmayananda. More specifically, it is a report of how the guru and disciple model within this religious institution has adapted in its transplantation, and how Western disciples navigate issues of authority, religious transmission and identity. This study sits within the fields of global Hinduism, post-colonial Indian objection to Orientalism and the emerging field of contemporary spirituality.

My findings explain how the classical guru and disciple model has transformed into one that affords the disciple complete autonomy in how they negotiate their relationship with the guru and adopt Hindu teachings and practices. It is only due to the initial altering of the traditional authority of the teacher-student relationship by the guru that religious transmission and changes within identity can be experienced by the 
disciple. In these inter-dependent relationships, transmission is based upon imbued authority granted to the guru and identity is based upon varying degrees of transmission experienced. The greater the authority, the greater the transmission, thus impacting a new identity assumed by the disciple. Jyotirmayananda's approach resonates with Mariana Caplan's model of conscious discipleship that is described as "fully empowered, intelligent, discriminating student-hood, which places the power and responsibility back in the hands of the spiritual student" (Caplan i). A critical thread within in her study is the notion of 'spiritual responsibility' that implies individuals take responsibility for their choices by accepting responsibility of consequences that arise from those choices (25). This is especially important when discussing the misuse of power with regards to gurus of the sixties in America (59).

The western disciples within Jyotirmayananda's communitus have also reimagined their religiosity as they identify themselves as 'spiritual, but not religious,' and practice Hinduism as their primary religion or as a parallel tradition to their existing worldview. My study reveals that disciples who identify themselves as followers of a religion other than Hinduism, view their primary religion through the lens of Yoga and Vedanta teachings, affirming they have become a better Christian or Jew etc. due to the guru's teachings. The guru has modified the Hindu tradition to become palatable and inclusive by promoting the philosophical imports of Yoga and Vedanta bereft of ritualistic observances. Religious syncretism occurring through the observance of nonHindu celebrations like Christmas and interpretation of sacred texts like the New Testament and the Dhammapada, further serve to reinvent Hinduism while attracting western disciples. 
As Jyotirmayananda develops his distinct form of Hindu practice, it is repackaged as 'Integral Yoga,' promoted as embodying "real religion" and "spirituality" that is based upon, ekam sat vipra bahuda vadanti, a statement from Rig Veda translated as "truth is one but is spoken of in many ways" (Jyotirmayananda). The teaching directly influences a disciple's acceptance or denial of religious affiliation and even the adoption of several religious identities. My data indicates that disciples desire the experience of different worldviews devoid of the pressure of committing to a single path. The phenomenon contributes to a new expression of the 'western Hindu' who is arguably not a follower of Hinduism, rather of sanatana dharma. The experience of Hinduism affords disciples agency in connecting with a relio-cultural past while adapting it to meet their modern modalities of living. Furthermore, the need for "purification of the west" as described by informants is essential in future studies within contemporary spirituality as Flood contends that 'global Hinduism' "is becoming a world religion alongside Christianity, Islam and Buddhism both for the Hindu diaspora communities and for westerners seeking their sense of belonging in non-western cultures and traditions" (Flood 265).

Overall, Swami Jyotirmayananda contributed to a conscious model of guru and discipleship and that could endure American culture for over forty years and has perhaps exemplified how a guru-led ashram can work in the United States and is one to be emulated. Stephen Jacobs states that Hindus in the West will utilize "symbolic resources: selecting, transforming and reinterpreting them in different ways that provide renewed relevance to the particular contexts of time and place" (Jacobs 145). The institutional structure of Jyotirmayananda's ashram supports Jacobs view as it is foundationally 
Hindu-inspired than traditionally Hindu in nature, this is in keeping with the trajectory of contemporary Hindu spirituality in the US. Combining symbolism, philosophy and cultural nuances of Hinduism, Jyotirmayananda has westernized his approach to discipleship simultaneously contributing to revitalizing Hindu spirituality in the United States. 


\section{BIBLIOGRAPHY}

Ambika. Disciple, Yoga Research Foundation. Personal Interview. 03 October 2013.

Archana. Disciple, Yoga Research Foundation. Personal Interview. 16 October 2013.

Atkinson, Paul, and Martyn Hammersley. "Ethnographyand participant observation." Handbook of qualitative research. Thou-sand Oaks, CA: Sage(1994).

Baird, Robert D. 1933-. Religion in Modern India. New Delhi: Manohar, 1981. Print.

Bhavani. Disciple, Yoga Research Foundation. Personal Interview. 18 January 2014.

Bridges, Hal. "Aldous Huxley : Exponent of Mysticism in America." Journal of the American Academy of Religion 37.4 (1969): 341-52. Print.

Brown, Judith M. (Judith Margaret). Gandhi : Prisoner of Hope. New Haven: Yale University Press, 1989. Print.

Cenkner, William 1930-. A Tradition of Teachers : Śankara and the Jagadgurus Today / William Cenkner. 1st ed. ed. Delhi: Motilal Banarsidass, 1983. Print.

Creswell, John W., and Creswell,John W.Qualitative inquiry and research design. Qualitative Inquiry \& Research Design : Choosing among Five Approaches. 2nd ed. ed. Thousand Oaks: Sage Publications, 2007. Print.

Dhiman, Satinder. "What is Vedanta?" Interbeing 4 (2010): 17. Print.

Divyananda, Swami. Disciple, Yoga Research Foundation. Personal Interview. 06 October 2013.

Ellis, Carolyn. The Ethnographic I : A Methodological Novel about Autoethnography. Walnut Creek, CA: AltaMira Press, 2004. Print.

Feuerstein, Georg. Holy Madness : The Shock Tactics and Radical Teachings of CrazyWise Adepts, Holy Fools, and Rascal Gurus. New York, NY: Arkana Books, 1992. Print.

Flood, Gavin D. An Introduction to Hinduism. Cambridge ; New York: Cambridge University Press, 1996. Print.

Forsthoefel, Thomas A., and Cynthia Ann Humes. Gurus in America. Albany, NY: State University of New York Press, 2005. Print. 
Fuller, Robert C. Spiritual, but Not Religious : Understanding Unchurched America. New York: Oxford University Press, 2001. Print.

Gall, Terry Lynn, Judith Malette, and Manal Guirguis-Younger. "Spirituality and Religiousness: A Diversity of Definitions." Journal of Spirituality in Mental Health 13.3 (2011): 158-81. Print.

Gennep, Arnold van. The Rites of Passage. Chicago: University of Chicago Press, 1960. Print.

Gold, Daniel 1947-. Comprehending the Guru : Toward a Grammar of Religious Perception / Daniel Gold. Atlanta, Ga: Scholars Press, 1988. Print.

Goldberg, Philip 1944-. American Veda : From Emerson and the Beatles to Yoga and Meditation : How Indian Spirituality Changed the West / Philip Goldberg. 1st ed. ed. New York: Harmony Books, 2010. Print.

Gomes, Michael. The Dawning of the Theosophical Movement. 1st ed. ed. Wheaton, Ill., U.S.A: Theosophical Pub. House, 1987. Print.

Goodman, Russell B. "East-West Philosophy in Nineteenth-Century America: Emerson and Hinduism." Journal of the History of Ideas 51.4 (1990): 625-45. Print.

Gyan, Satish Chandra 1938-. Sivananda and His Ashram / Satish Chandra Gyan. Madras: Published for Christian Institute for the Study of Religion and Society, Bangalore by Christian Literature Society, 1980. Print.

---. "Swami Sivananda and the Divine Life Society: An Illustration of Revitalization Movement." Ph.D. Temple University, 1979. Print.United States -- Pennsylvania: .

Hatcher, Brian A. "Remembering Rammohan: An Essay on the (Re-)Emergence of Modern Hinduism." History of Religions 46.1 (2006): 50-80. Print.

Jackson, Carl T. The Oriental Religions and American Thought : Nineteenth-Century Explorations. Westport, Conn: Greenwood Press, 1981. Print.

Jacobs, Stephen. Hinduism Today. London ; New York: Continuum, 2010. Print.

Jones, Robert Alun. Emile Durkheim : An Introduction to Four Major Works. Beverly Hills: Sage Publications, 1986. Print.

Jyotirmayananda, Swami (@SwamijiYRF)."Grow in the image of God. Discover within yourself the Love of Christ, the Compassion of Buddha, the Bliss of Krishna! Blessings! Om!.”19 January 2013. 6:01AM. Tweet. 
Jyotirmayananda, Swami (@SwamijiYRF)."Learn the art of divine detachment. Detach and Attach! Detach from the world of illusion and turn to God. Serve. Love. Meditate. Realize. OM.” 19 January 2013. 6:01AM. Tweet.

Jyotirmayananda, Swami. Guru, Yoga Research Foundation. Personal Interview. 01 August 2013.

Jyotirmayananda, Swami. Integral Yoga. Miami, FL: Yoga Research Foundation, 2009. Print.

Jyotirmayananda, Swami. Yoga in Practice. Miami, FL: Yoga Research Foundation, 1974. Print.

King, Richard, and Inc NetLibrary. Orientalism and Religion Postcolonial Theory, India and 'the Mystic East'. London; New York: Routledge, 1999. Print.

King, Richard. Indian Philosophy: An Introduction to Hindu and Buddhist Thought. Georgetown University Press, 0000. Print.

Klass, Morton. Singing with Sai Baba: The Politics of Revitalization in Trinidad. Boulder, Colo: Westview Press, 1991. Print.

Larson, Gerald James. "Differentiating the Concepts of "Yoga" and "Tantra" in Sanskrit Literary History." Journal of the American Oriental Society 129.3 (2009): 487-98. Print.

Lavie, Smadar, and Ted Swedenburg. Displacement, Diaspora, and Geographies of Identity. Durham, NC: Duke University Press, 1996. Print.

Lunior, Bob. Disciple, Yoga Research Foundation. Personal Interview. 21 September 2013.

Maheswari. Disciple, Yoga Research Foundation. Personal Interview. 21 December 2013.

Miller, David M. PhD, and Dorothy C. joint author Wertz. Hindu Monastic Life : The Monks and Monasteries of Bhubaneswar. Rev. ed. ed. New Delhi: Manohar, 1996. Print.

Nelson, Annabelle. "The Spacious Mind: Using Archetypes for Transformation Towards Wisdom." Humanistic Psychologist 35.3 (2007): 235-45. Print.

Oldmeadow, Harry. "Sankara's Doctrine of Maya." Asian Philosophy 2.2 (1001): 131. Print. 
Padma Devi. Disciple, Yoga Research Foundation. Personal Interview. 14 December 2013.

Parlee, Bert. "Strivings Toward Integrity: Surrender and Autonomy in the Guru-Disciple Relationship." Ph.D. California Institute of Integral Studies, 1993. Print.United States -- California: .

Prakash, Buddha. "The Hindu Philosophy of History." Journal of the History of Ideas 16.4 (1001): 494. Print.

Prana. Disciple, Yoga Research Foundation. Personal Interview. 15 October 2013.

Radha.. Disciple, Yoga Research Foundation. Personal Interview. 15 January 2014.

Ramesh. Disciple, Yoga Research Foundation. Personal Interview. 25 September 2013.

Robinson, David. Emerson and the Conduct of Life : Pragmatism and Ethical Purpose in the Later Work. Cambridge England] ; New York, NY, USA: Cambridge University Press, 1993. Print.

Sankara. Disciple, Yoga Research Foundation. Personal Interview. 25 October 2013.

Sharadananda, Swami. Disciple, Yoga Research Foundation. Personal Interview. 16 October 2013.

Seminar on the Nature of Guruship (1974 : Christian Institute of,Sikh Studies, Sikh Studies Christian Institute of, and Clarence O. 1935- McMullen. The Nature of Guruship. Delhi: Published for the Christian Institute of Sikh Studies, Batala, by I.S.P.C.K, 1976. Print.

Shastri, Gaurinath Bhattacharyya. A Concise History of Classical Sanskrit Literature. 2d ed. ed. London, New York: Oxford University Press, 1960. Print.

Sivananda, Swami 1887. Autobiography of Swami Sivananda. 2d ed. ed. Shivanandanagar: Divine Life Society, 1980. Print.

---. Sivananda: Biography of a Modern Sage. Divine Life Society, 0000. Print.

Sri Arjuna. Disciple, Yoga Research Foundation. Personal Interview. 03 October 2013.

Sri Hari. Disciple, Yoga Research Foundation. Personal Interview. 24 September 2013.

Strauss, Sarah. "The Master's Narrative: Swami Sivananda and the Transnational Production of Yoga." Journal of Folklore Research 39 (2002): 217+. Print. 
The Jewish Spirituality Series. Dir. Katz, Nathan. Temple Israel, Miami Florida, USA, 2013.

Turner, Victor W. (Victor Witter). The Ritual Process: Structure and Anti-Structure. London: Routledge \& K. Paul, 1969. Print.

Varenne, Jean. Yoga and the Hindu Tradition. Chicago: University of Chicago Press, 1976. Print.

Vasudeva. Disciple, Yoga Research Foundation. Personal Interview. 05 November 2013

Wach, Joachim. "Master and Disciple: Two Religio-Sociological Studies." The Journal of Religion 42.1 (1962): 1-21. Print.

Weber, Max, A. M. (A Henderson, and Talcott Parsons. The Theory of Social and Economic Organization. Translated by A.M. Henderson and Talcott Parsons; Edited with an Introd. by Talcott Parsons. [1st American ed.] ed. New York: Oxford University Press, 1947. Print.

Weber, Max, S. N. (S Eisenstadt, and S. N. (S Eisenstadt. Max Weber on Charisma and Institution Building; : Selected Papers. Chicago: University of Chicago Press, 1968. Print.

Weiser, Lee E. "The Bhagavad Gita: A Depth Psychological Perspective." Ph.D. Pacifica Graduate Institute, 1999. Print.United States -- California: .

Wilber, Ken, Daniel P. Brown, and Jack Engler. Transformations of Consciousness : Conventional and Contemplative Perspectives on Development. 1st ed. ed. Boston : New York: New Science Library ; Distributed in the U.S. by Random House, 1986. Print.

Williams, Raymond B. A Sacred Thread: Modern Transmission of Hindu Traditions in India and Abroad. Columbia University Press ed. ed. New York: Columbia University Press, 1996. Print.

Williamson, Lola. Transcendent in America : Hindu-Inspired Meditation Movements in America. New York: New York University Press, 2010. Print.

Yoga Research Foundation. "Let your every action be an act of worship of God. God is not limited to temples and churches alone. God is everywhere. He fills the earth and the Heavens. He sees through all eyes, and thinks through all minds." 27 November 2013. [12/01/2013 www.facebook.com/yogaresearch]. 